Review

\title{
Progress in Tribological Properties of Nano-Composite Hard Coatings under Water Lubrication
}

\author{
Qianzhi Wang ${ }^{1,2}$ and Fei Zhou ${ }^{1,2, *}$ \\ 1 State Key Laboratory of Mechanics and Control of Mechanical Structures, Nanjing University of Aeronautics \\ and Astronautics, Nanjing 210016, Jiangsu, China; qz.wang@nuaa.edu.cn \\ 2 College of Mechanical and Electrical Engineering, Nanjing University of Aeronautics and Astronautics, \\ Nanjing 210016, Jiangsu, China \\ * Correspondence: fzhou@nuaa.edu.cn
}

Academic Editor: Robert Wood

Received: 28 June 2016; Accepted: 14 February 2017; Published: 17 February 2017

\begin{abstract}
The tribological properties, under water-lubricated conditions, of three major nano-composite coatings, i.e., diamond-like carbon (DLC or a-C), amorphous carbon nitride $\left(\mathrm{a}-\mathrm{CN}_{x}\right)$ and transition metallic nitride-based (TiN-based, $\mathrm{CrN}$-based), coatings are reviewed. The influences of microstructure (composition and architecture) and test conditions (counterparts and friction parameters) on their friction and wear behavior under water lubrication are systematically elucidated. In general, DLC and a- $\mathrm{CN}_{x}$ coatings exhibit superior tribological performance under water lubrication due to the formation of the hydrophilic group and the lubricating layer with low shear strength, respectively. In contrast, TiN-based and $\mathrm{CrN}$-based coatings present relatively poor tribological performance in pure water, but are expected to present promising applications in sea water because of their good corrosion resistance. No matter what kind of coatings, an appropriate selection of counterpart materials would make their water-lubricated tribological properties more prominent. Currently, Si-based materials are deemed as beneficial counterparts under water lubrication due to the formation of silica gel originating from the hydration of Si. In the meantime, the tribological properties of nano-composite coatings in water could be enhanced at appropriate normal load and sliding velocity due to mixed or hydrodynamic lubrication. At the end of this article, the main research that is now being developed concerning the development of nano-composite coatings under water lubrication is described synthetically.
\end{abstract}

Keywords: nano-composite coatings; water lubrication; tribochemical reaction; friction; wear

\section{Introduction}

Lubricant oil has been widely used in various driving systems in the machinery industry [1]. Unfortunately, the source of lubricating oil, i.e., petroleum, is non-renewable. Moreover, the leakage and burning of lubricating oil undoubtedly pollute the natural environment and impose a potential hazard on human health. Thus, the proposal and development of green tribology, i.e., environmentally-friendly tribology, have become a priority to minimize pollution and conserve petroleum resources $[2,3]$. Under such a background, water lubrication as a favorable alternative has intensively attracted academics concerns. However, the key factor to its successful application is to overcome two major disadvantages. One is the poor lubrication effect of water because of a very thin lubricating film (1/1000 of oil film thickness), while the otheris the strong oxidation ability of water leading to an unpredictable corrosion to metal components [4,5]. Therefore, the design and development of novel materials with good water lubrication is of paramount importance to realize a successful application under water lubrication. 
Currently, three kinds of materials, i.e., organic polymer, ceramics and nano-composite coatings, are often used under water lubrication [4]. Organic polymer is able to exhibit a low friction coefficient and a favorable ability of reducing vibration, but its poor thermal stability and aging issue shorten its service life under water lubrication. In contrast, ceramics overcome the drawbacks of organic polymer and have low density, high hardness, as well as good wear resistance. However, their brittleness leads to the high difficulty of manufacturing, and therefore, their cost increases intensively. Fortunately, the deposition of nano-composite coatings is a relatively easy and inexpensive way to protect tribopairs under water lubrication. It not only takes the advantage of the ductility of the metal substrate, but also presents good tribological properties. More importantly, the tribological properties of nano-composite coatings in water can be adjusted precisely by tailoring their microstructure (composition and architecture) and test conditions (counterparts and friction parameters) according to the actual demands.

During the past ten years, as protective materials diamond-like carbon (DLC or a-C), a-CN $\mathrm{CN}_{x}$ TiN-based, CrN-based coatings, as well as self-lubricating metal matrix composites [6-8] have had more attention paid. Subsequently, their tribological properties in ambient, vacuum and aqueous environments have been investigated. At the request of environment protection, the water-lubricated behaviors of nano-composite coatings, such as DLC(a-C), a- $\mathrm{CN}_{x}$ and TiN-based and CrN-based coatings, especially $\mathrm{CrBN}$ [9], $\mathrm{CrSiCN}[10,11]$ and $\mathrm{CrBCN}$ [12], in the last two years have become a research hotspot. This tendency has been well demonstrated by an increasing number of relevant publication papers, as well as an increasing citation number per year (Figure 1). It is obviously indicated that more and more academics around the world have started to engage themselves in the study ofthe friction and wear behaviors of nano-composite coatings under water lubrication [13]. Therefore, this paper aims to state the progress in the tribological properties of nano-composite coatings in pure water lubrication (distilled and deionized water), to classify the influence factors, to reveal the corresponding lubrication and wear mechanisms, as well as to highlight the main research concerning the development of nano-composite coatings under water lubrication.

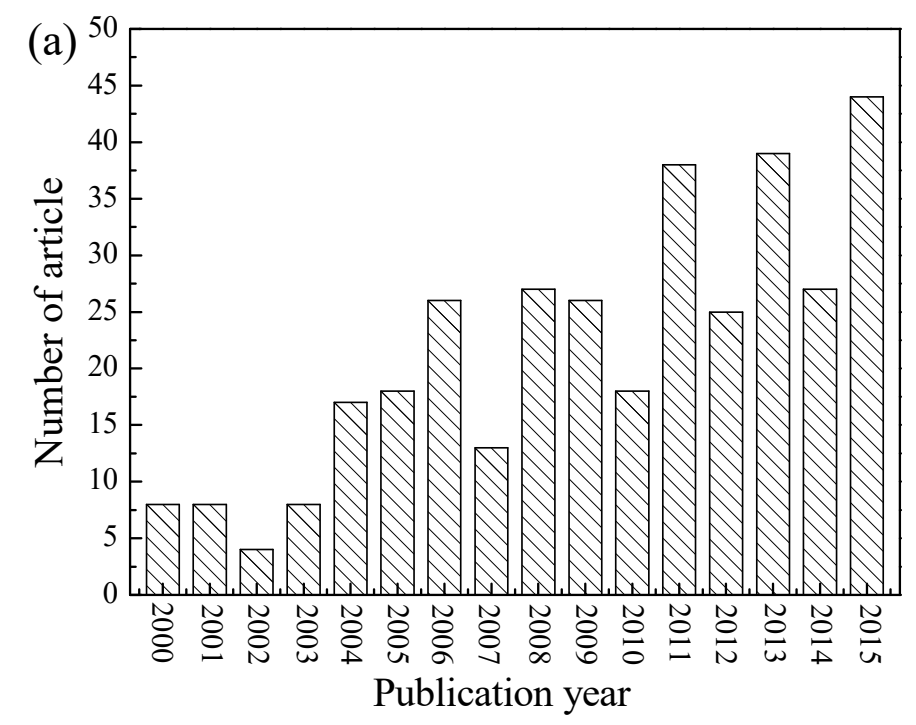

Figure 1. Cont. 


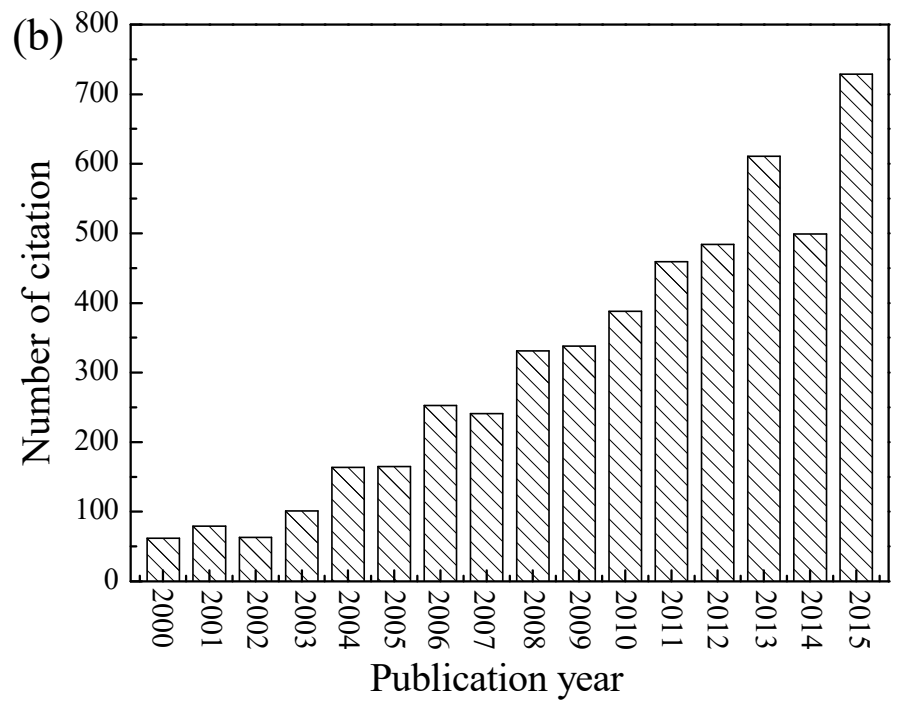

Figure 1. (a) Number of articles and (b) the number of citations in the past 15 years.

\section{Tribological Properties of DLC Coatings under Water Lubrication}

Because of the mixed structure of $\mathrm{sp}^{2}$ and $\mathrm{sp}^{3}$ hybrid orbits, DLC coatings exhibit excellent mechanical properties and stable chemical inertness. Furthermore, the graphitization of DLC coatings in use generates a thin layer with low shear strength that contributes to a low friction coefficient generally. It has been reported that the tribological properties of DLC coatings under water lubrication were strongly dependent on their microstructure (composition and architecture) and test conditions (counterparts and friction parameters), which will be stated in detail as follows.

\subsection{Influence of Microstructure}

\subsubsection{Composition}

In terms of different carbon sources (graphite target or hydrocarbon gas) used during the deposition process, DLC coatings can be divided into two categories, including hydrogen-free DLC $(\mathrm{a}-\mathrm{C})$ and hydrogenated DLC:H $(\mathrm{a}-\mathrm{C}: \mathrm{H})$ coatings. This distinction significantly determines the tribological properties of DLC coatings under water lubrication. For instance, Ronkainen et al. $[14,15]$ deposited a-C:H $(30$ at $\% \mathrm{H})$ and a-C coatings on stainless steel (AISI 440B) via using radio frequency plasma-assisted chemical vapor deposition (rf-PACVD) and cathode vacuum arc discharge, respectively. It was found that, under water-lubricated condition, severe delamination occurred on a-C:H coatings, while a non-detective wear was found on a-C coatings. A similar phenomenon has also been reported in [16]. Moreover, Andersson et al. $[17,18]$ found that the friction coefficient of a-C:H coatings increased gradually with increasing water vapor pressure (relative humidity from $0.04 \%$ to $4.00 \%$ ). As a consequence, researchers thought that the presence of hydrogen in DLC coatings would deteriorate their tribological properties in water. Nevertheless, some DLC:H coatings still keep intact and present a good tribological performance under water lubrication. For instance, a-C:H/a-C tribopair exhibited a low friction coefficient of 0.04 and a low coating wear rate of $1.5 \times 10^{-8} \mathrm{~mm}^{3} / \mathrm{Nm}$, which were yet higher than those of a-C/a-C tribopair $\left(0.03\right.$ and $\left.0.5 \times 10^{-8} \mathrm{~mm}^{3} / \mathrm{Nm}\right)$ under water lubrication [19]. Based on the results mentioned above, it could be shown that the presence of hydrogen in DLC coatings negatively influences their tribological properties in water-lubricated condition. Namely, DLC (a-C) coatings, as compared with DLC:H (a-C:H) coatings, are liable to present a better tribological performance under water lubrication, as listed in Table 1. 
Table 1. Tribological properties of a-C and a-C:H coatings under water lubrication.

\begin{tabular}{|c|c|c|c|c|c|c|}
\hline Refs. & Tribopairs & Water & $\begin{array}{c}\text { Load } \\
(\mathrm{N})\end{array}$ & $\begin{array}{l}\text { Velocity } \\
(\mathrm{m} / \mathrm{s})\end{array}$ & $\begin{array}{c}\text { Friction } \\
\text { Coefficient } \mu\end{array}$ & $\begin{array}{c}\text { Coating Wear Rate } \\
\left(\mathrm{mm}^{3} / \mathrm{Nm}\right)\end{array}$ \\
\hline [14] & $\begin{array}{c}\mathrm{a}-\mathrm{C} / \alpha-\mathrm{Al}_{2} \mathrm{O}_{3} \\
\mathrm{a}-\mathrm{C}: \mathrm{H} / \alpha-\mathrm{Al}_{2} \mathrm{O}_{3}\end{array}$ & Distilled & 5 & 0.004 & $\begin{array}{l}0.05 \\
0.69\end{array}$ & $\begin{array}{c}\text { Immeasurable wear } \\
\text { Worn through }\end{array}$ \\
\hline [15] & $\begin{array}{c}\mathrm{a}-\mathrm{C} / \alpha-\mathrm{Al}_{2} \mathrm{O}_{3} \\
\mathrm{a}-\mathrm{C}: \mathrm{H} / \alpha-\mathrm{Al}_{2} \mathrm{O}_{3}\end{array}$ & Distilled & 5 & 0.004 & $\begin{array}{c}0.03 \\
-\end{array}$ & $\begin{array}{l}\text { Immeasurable wear } \\
\text { Worn through }\end{array}$ \\
\hline [16] & $\begin{array}{l}\text { a-C/tungsten carbide WC- } 6 \% \text { Co } \\
\text { a-C:H/tungsten carbide WC- } 6 \% \text { Co }\end{array}$ & Distilled & 40 & 0.05 & $\begin{array}{c}0.08 \\
-\end{array}$ & $\begin{array}{c}1.1 \times 10^{-8} \\
\text { Worn through }\end{array}$ \\
\hline [19] & $\begin{array}{c}a-C / a-C \\
a-C: H / a-C\end{array}$ & Distilled & 5 & 0.05 & $\begin{array}{l}0.03 \\
0.04\end{array}$ & $\begin{array}{l}0.5 \times 10^{-8} \\
1.5 \times 10^{-8}\end{array}$ \\
\hline
\end{tabular}

With regard to DLC:H (a-C:H) coatings, the hydrogen concentration plays an important role in affecting their tribological properties in water. For example, the improved tribological performance of DLC:H coatings under water lubrication was obtained when $\mathrm{H}$ concentration in DLC:H coatings was low [20]. Similarly, the DLC:H coatings with the lowest $\mathrm{H}$ content ( 25 at \%) showed the lowest coating wear rate of $3.0 \times 10^{-9} \mathrm{~mm}^{3} / \mathrm{Nm}$ [21]. Thus, an optimal DLC:H/316L tribopair even exhibited a lower friction coefficient (by 0.01) under water lubrication than that under oil lubrication [22]. On the basis of this, the tribological properties of DLC:H coatings $(30 \mathrm{at} \% \mathrm{H})$ in water were intensively subjected to bias voltage [23]. In contrast, the fraction of $\mathrm{sp}^{2}$ hybrid bond in DLC(a-C) coatings is crucial for their tribological properties under water lubrication. Wang et al. [24] deposited different graphite-like carbon (GLC) coatings on stainless steel $(18 \mathrm{Cr}-12 \mathrm{Ni}-2.5 \mathrm{Mo})$ with adjusting the concentration of $\mathrm{sp}^{2}$ hybrid bond in coatings. It was found that the lowest friction coefficient and wear rate of the GLC/tungsten carbide (WC) tribopair in water were obtained as the fraction of $\mathrm{sp}^{2}$ in GLC coatings reached $69 \%$.

As stated before, DLC coatings are comprised of $\mathrm{sp}^{2}$ and $\mathrm{sp}^{3}$ hybrid bonds. Among them, the $\mathrm{sp}^{3}$ hybrid bond is deemed to impose a high residual stress on DLC coatings, thus leading to an unexpected delamination. Some researchers have reported that the incorporation of non-metal or metal elements into DLC coatings was able to release residual stress. Subsequently, the bonding strength between coatings and substrate was enhanced, and therefore, the tribological properties of DLC:H (a-C:H) and DLC (a-C) coatings in water were improved significantly. As shown in Figure 2a, Tanaka et al. $[25,26]$ demonstrated that the friction coefficient of the DLC:H/AISI 440C tribopair in deionized water was reduced after 0.24 at \% F and 6.6 at \% Si were incorporated into DLC coatings. On the contrary, Si-DLC:H (2.3 at \% Si) and Si-DLC:H coatings yet exhibited a higher friction coefficient than that of pure DLC:H coatings mating with AISI 440C [26] and DLC:H [27] (see Figure 2a).

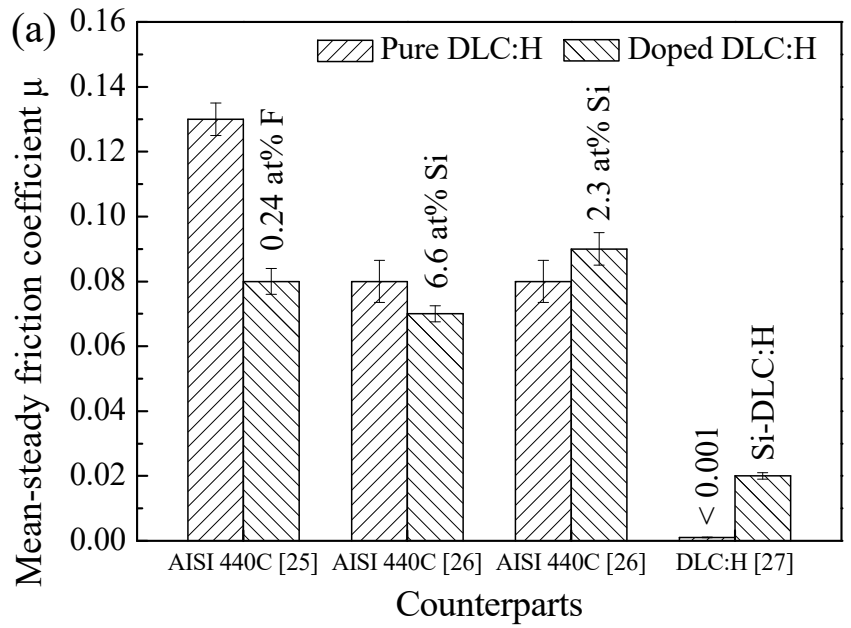

Figure 2. Cont. 


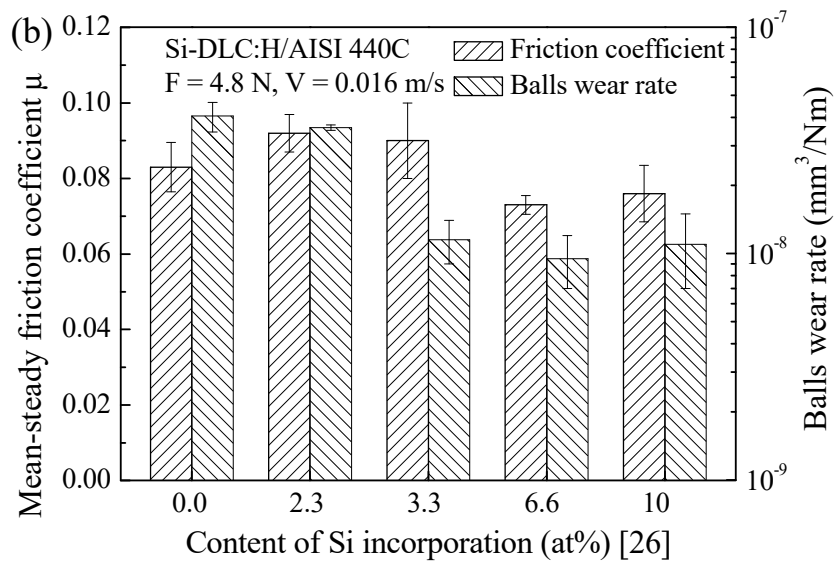

Figure 2. (a) Comparison of the friction coefficient of diamond-like carbon (DLC):H and doped DLC:H coatings [25-27]; (b) evolution of the mean-steady friction coefficient of the Si-DLC:H/stainless steel(AISI 440C) tribopair as a function of Si content [26].

Thus, two important points can be drawn based on the results shown in Figure 2a. One is that element incorporation cannot guarantee improving the tribological properties of DLC:H coatings under water lubrication [27]. Another is that an adjustment of doping element content is extremely necessary for achieving the best tribological performance of the doped DLC:H coatings. This deduction can be further verified by the results in [26], as shown in Figure 2b. In deionized water, Ar-DLC:H coatings deposited at a bias voltage of $-3.0 \mathrm{kV}$ (a range from -0.5 to $-3.0 \mathrm{kV}$ ) exhibited the lowest friction coefficient and coating wear rate $\left(0.1\right.$ and $\left.8.0 \times 10^{-9} \mathrm{~mm}^{3} / \mathrm{Nm}\right)$ [28], whilst Si-DLC:H $(3.9$ at $\% \mathrm{Si}) / \mathrm{Si}_{3} \mathrm{~N}_{4}$ and Si-DLC:H (7.3 at \% Si) / AISI 440C tribopairs presented the lowest friction coefficient of 0.005 and 0.09 , respectively $[29,30]$. In addition, Zhou et al. [31-33] pointed out that an incorporation of Ti at 0.98 at \% could reduce the friction coefficient and wear rate of a-C/ $\mathrm{Al}_{2} \mathrm{O}_{3}$ tribopair, while an incorporation of $\mathrm{Cr}$ at 3.0 at \% could shorten the running-in distance of the a-C/stainless steel (SUS440C) tribopair from $150 \mathrm{~m}$ to $50 \mathrm{~m}$ in deionized water. Nevertheless, a higher doping content of $\mathrm{Ti}(>0.98 \mathrm{at} \%)$ or $\mathrm{Cr}$ $(>3.0$ at $\%$ ) would deteriorate the tribological properties of a-C coatings under water lubrication; even a premature failure.

Based on the above-mentioned results, it can be concluded that the presence of hydrogen in DLC coatings negatively influences their water-lubricated tribological properties. In other words, hydrogen-free DLC $(\mathrm{a}-\mathrm{C})$ coatings are superior to hydrogenated DLC:H $(\mathrm{a}-\mathrm{C}: \mathrm{H})$ coatings under water lubrication. For each category, DLC coatings containing a higher $\mathrm{sp}^{2}$ fraction while DLC:H coatings containing a lower $\mathrm{H}$ concentration are liable to exhibit good tribological properties under water lubrication. In addition, the tribological performance of DLC:H or DLC coatings under water lubrication can be enhanced via non-metal ( $\mathrm{Si}$ ) or metal elements' ( $\mathrm{Ti}, \mathrm{Cr}$ ) incorporation. However, the optimal doping concentration is usually at a low range that often varies from 1.0 at \% to 7.0 at $\%$.

\subsubsection{Architecture}

The design of the architecture, i.e., bi-layer or multilayer structure, is another effective approach to improve the tribological properties of DLC coatings in water. For instance, Ohana et al. [34] and Park et al. [35] designed Si-DLC:H/DLC:H and Si/DLC:H bi-layer coatings with different thickness ratios and investigated their wear resistance in deionized water. The results showed that Si-DLC:H/DLC:H coatings with a thickness distribution of $0.16 \mu \mathrm{m} / 1.40 \mu \mathrm{m}$ exhibited the lowest wear rate of $4.8 \times 10^{-8} \mathrm{~mm}^{3} / \mathrm{Nm}$ while sliding against AISI $440 \mathrm{C}$ balls, while the wear resistance of $\mathrm{Si} / \mathrm{DLC}: \mathrm{H}$ coatings was proportional to the thickness of Si interlayer (from 0.4 to $1.6 \mathrm{~nm}$ ). As regards the multilayer coatings, Ronkainen et al. [14] found that a-C:H/a-Si $i_{1-x} C_{x}: H$ coatings with a constant period (not mentioned in the paper) exhibited a lower wear rate $\left(0.2 \times 10^{-6} \mathrm{~mm}^{3} / \mathrm{Nm}\right)$ as compared 
with monolithic a-C:H coatings $\left(0.9 \times 10^{-5} \mathrm{~mm}^{3} / \mathrm{Nm}\right)$ due to an inhibition effect on crack propagation. Moreover, the results in [36] demonstrated that when the period was $7.7 \mathrm{~nm}, \mathrm{Cr}(\mathrm{N}) / \mathrm{C}(\mathrm{DLC})$ coatings mating with the $\mathrm{Al} 319$ pin presented a friction coefficient of 0.33 without any obvious wear marks in distilled water. However, when the period further decreased to $3.4 \mathrm{~nm}$, the friction coefficient increased to 0.43 with many obvious grooves on the wear track [36].

It is obviously indicated that the wear resistance of DLC coatings in water could be enhanced via architecture design based on a high hardness, a good load capacity and a strong inhibition effect on the propagation of micro-crack. It is worth noting that, the same as element incorporation, there is an optimal architecture design to realize the improvement in the tribological performance of DLC coatings under water lubrication. According to the above-mentioned [34-36], a superior tribological performance of DLC multilayer coatings in water was generally obtained by introducing a thicker additive layer, such as Si-DLC:H, Si and $\mathrm{Cr}(\mathrm{N})$.

\subsection{Influence of Test Conditions}

\subsubsection{Counterpart}

As we known, one tribopair consists of two components, i.e., coatings and counterparts. Thus, besides the coatings themselves, the natural features of the counterpart, such as surface roughness, hardness and chemical property, would induce quite different friction behaviors of DLC coatings under water lubrication. For the same counterpart, Ohana et al. found that the wear rate of counterparts (AISI 306 and brass) was proportional to the surface roughness of DLC:H coatings [37], while the friction coefficient of the DLC:H/AISI 440C tribopair was inversely proportional to the surface roughness of AISI 440C balls [38]. Similarly, after polishing DLC:H coatings by diamond suspension, a low and stable friction coefficient of the DLC:H/SUS630 tribopair in distilled water was reported in [39].

As listed in Table 2, the friction coefficient and coating wear rate of DLC (a-C) coatings mating with different counterparts vary accordingly. Specifically, a-C coatings presented a lower friction coefficient and a better wear resistance when sliding against carbon-based counterparts compared to CrN-based counterparts due to the different hardness of the counterparts and the types of debris [19]. The wear rate of nano-crystal diamond (NCD) films decreased when sliding against a soft ball compared to a hard ball [40]. On the other hand, the order of the wear rate for three rubbers FKM 26, NBR 7201 and EPDM 8370 sliding against $\mathrm{Cr} / \mathrm{CrN} /$ GLC coatings was arranged as: $w_{\mathrm{NBR}}>w_{\mathrm{FKM}}>w_{\mathrm{EPDM}}$ due to their different tensile strengths [41]. Owing to the reduced adhesive wear and good solid lubrication, the DLC/CoCrMo tribopair showed a lower friction coefficient (0.025) and much less wear depth $(70 \mathrm{~nm})$ than the DLC $/ \mathrm{Al}_{2} \mathrm{O}_{3}$ tribopair [42]. The wear rate of GLC coatings sliding against $\mathrm{Al}$ suffered a high wear rate due to severe adhesion and oxidation [43], while the Cr-plated ball played an important role informing a lubrication film contributing to a low friction coefficient [44].

Obviously, the tribological properties of DLC coatings sliding against various counterparts under water lubrication are closely attributed to different wear mechanisms based on different hardness [19,40], oxidation resistance [43] and the chemical stability [44] of the counterparts. Thus, after optimizing coatings' composition and architecture, an appropriate selection of counterpart material is expected to further enhance the tribological properties of DLC coatings in water. On the one hand, a counterpart that is of a lower hardness than DLC coatings, such as CoCrMo, has a self-lubricating effect, such as the carbon-based counterpart, or that easily forms lubrication film in water, such as $\mathrm{Cr}$, is the best selection. On the other hand, regardless of the counterpart, DLC coatings with a lower surface roughness are expected to exhibit a low friction coefficient under water lubrication due to reduced abrasive wear. Thus, an appropriate polishing for DLC coatings is beneficial to obtain a better friction and wear behavior. 
Table 2. Tribological properties of DLC coatings mating with different counterparts under water lubrication. GLC, graphite-like carbon.

\begin{tabular}{|c|c|c|c|c|c|c|}
\hline Refs. & Tribopairs & Water & $\begin{array}{l}\text { Load } \\
(\mathrm{N})\end{array}$ & $\begin{array}{l}\text { Velocity } \\
(\mathrm{m} / \mathrm{s})\end{array}$ & $\begin{array}{c}\text { Friction } \\
\text { Coefficient } \mu\end{array}$ & Wear Rate $\left(\mathrm{mm}^{3} / \mathrm{Nm}\right)$ \\
\hline [19] & $\begin{array}{c}\mathrm{a}-\mathrm{C} / \mathrm{a}-\mathrm{C} \\
\mathrm{a}-\mathrm{C} / \mathrm{a}-\mathrm{C}: \mathrm{H} \\
\mathrm{a}-\mathrm{C} / \mathrm{CrN} \\
\mathrm{a}-\mathrm{C} / \mathrm{CrSiN}\end{array}$ & Distilled & 5 & 0.05 & $\begin{array}{l}0.030 \\
0.040 \\
0.041 \\
0.042\end{array}$ & $\begin{array}{l}\text { Coatings: } 0.5 \times 10^{-8} \\
\text { Coatings: } 1.5 \times 10^{-8} \\
\text { Coatings: } 3.1 \times 10^{-8} \\
\text { Coatings: } 3.9 \times 10^{-8}\end{array}$ \\
\hline [40] & $\begin{array}{l}\text { Micro-crystalline } \\
\text { diamond(MCD)/ } \\
\text { Nano-crystalline } \\
\text { diamond(NCD) } \\
\text { MCD/MCD } \\
\text { NCD/NCD } \\
\text { NCD/MCD }\end{array}$ & Deionized & 4 & 0.128 & $\begin{array}{l}0.025 \\
0.023 \\
0.023 \\
0.024\end{array}$ & $\begin{array}{c}\text { immeasurable } \\
\text { immeasurable } \\
\text { Coatings: } 4.3 \times 10^{-7} \\
\text { Coatings: } 9.5 \times 10^{-7}\end{array}$ \\
\hline$[41]$ & $\begin{array}{c}\text { GLC/rubber EPDM } 8370 \\
\text { GLC/rubber FKM } 26 \\
\text { GLC/rubber NBR } 7201\end{array}$ & Distilled & 100 & 0.6 & $\begin{array}{l}0.06 \\
0.03 \\
0.04\end{array}$ & $\begin{array}{l}\text { Counterpart: } 0.8 \times 10^{-6} \\
\text { Counterpart: } 2.2 \times 10^{-6} \\
\text { Counterpart: } 0.3 \times 10^{-5}\end{array}$ \\
\hline [42] & $\begin{array}{c}\mathrm{DLC} / \mathrm{CoCrMo} \\
\mathrm{DLC} / \mathrm{Al}_{2} \mathrm{O}_{3}\end{array}$ & Pure & 2 & 0.025 & $\begin{array}{l}0.025 \\
0.038\end{array}$ & $\begin{array}{l}\text { Coatings: } 70 \mathrm{~nm} \text { in depth } \\
\text { Coatings: } 700 \mathrm{~nm} \text { in depth }\end{array}$ \\
\hline [43] & $\begin{array}{c}\text { GLC/Ti } \\
\text { GLC/GCr15 } \\
\text { GLC/brass } \\
\text { GLC/Al }\end{array}$ & Distilled & 5 & 0.078 & $\begin{array}{l}0.14 \\
0.11 \\
0.09 \\
0.10\end{array}$ & $\begin{array}{l}\text { Coatings: } 1.3 \times 10^{-8} \\
\text { Coatings: } 2.5 \times 10^{-8} \\
\text { Coatings: } 3.1 \times 10^{-8} \\
\text { Coatings: } 2.6 \times 10^{-7}\end{array}$ \\
\hline$[44]$ & $\begin{array}{c}\text { DLC:H/AISI 440C } \\
\text { DLC:H/Cr }\end{array}$ & Deionized & 2 & 0.016 & $\begin{array}{l}0.11 \\
0.09\end{array}$ & $\begin{array}{l}\text { Coatings: } 2.0 \times 10^{-8} \\
\text { Coatings: } 6.0 \times 10^{-8}\end{array}$ \\
\hline
\end{tabular}

\subsubsection{Aqueous Solution}

Up to now, distilled water $(18 \mathrm{M} \Omega)$ is a major lubricant used in existing literature regarding the tribological properties of DLC coatings in water. In fact, some actual applications, such as nuclear reactors, have to use heavy water. In addition, the concentration of calcium and magnesium compounds in water closely depends on different areas. Therefore, investigations on the friction behavior of DLC coatings in different kinds of water are inevitable. Wu et al. [45,46] compared the tribological properties of DLC:H/AISI $440 \mathrm{C}$ tribopairs in three types of aqueous solutions, i.e., $\mathrm{H}_{2} \mathrm{O}, \mathrm{D}_{2} \mathrm{O}$ and $\mathrm{H}_{2}{ }^{18} \mathrm{O}$. As shown in Figure 3a, common water $\left(\mathrm{H}_{2} \mathrm{O}\right)$ prefers to highlight the tribological properties of DLC:H coatings due to the tribochemical reactions as follows:

$$
\begin{gathered}
\mathrm{C}-\mathrm{CH} \stackrel{\text { mechanical stimulation }}{\longrightarrow} \mathrm{C}+\mathrm{CH} \\
\mathrm{CH}+\mathrm{H} \text { (from water) } \rightarrow \mathrm{CH}_{2} \\
\mathrm{C}+\mathrm{OH} \text { (from water }) \rightarrow \mathrm{COH}
\end{gathered}
$$

The $\mathrm{C}-\mathrm{CH}$ bond in DLC:H coatings was broken by mechanical stimulation during the friction process. Subsequently, the separated group of $\mathrm{CH}$ was prone to achieve a $\mathrm{H}$ atom from a $\mathrm{H}_{2} \mathrm{O}$ molecular to form $\mathrm{CH}_{2}$, whilst the separated $\mathrm{C}$ bonded with the group of $\mathrm{OH}$ to form $\mathrm{COH}$. This $\mathrm{COH}$, which is hydrophilic, contributed to the good tribological properties of DLC:H coatings in common water $\left(\mathrm{H}_{2} \mathrm{O}\right)$. As regards the Si-DLC:H coating, the occurrence of the tribochemical reaction between Si-DLC:H and $\mathrm{D}_{2} \mathrm{O}$ was also considered to be responsible for its low friction and wear behavior [47].

On the other hand, Uchidate et al. [48] found that the accumulation of alumina on brass aggravated the wear of DLC:H coatings in pure water, while the ions in tap-water slowed down the accumulation rate of alumina on brass. Therefore, the wear rate of DLC:H coatings in tap-water was lower than that of DLC:H coatings in pure water even at different temperatures (see Figure $3 b$ ). On the basis of this, a comparison between the tribological properties of the DLC:H $(30$ at $\% \mathrm{H}) /$ brass tribopair in hard and soft water demonstrated that the high concentration of $\mathrm{Ca}^{2+}$ in hard water was beneficial to lower 
the friction coefficient and wear rate of DLC:H/brass tribopair due to the formation of a tribolayer containing $\mathrm{Ca}$ and $\mathrm{O}$ [49]. In addition, Uchidate et al. [48-50] also found that the high temperature inhibited the formation of a whole lubricating film in water, which led to a high friction coefficient and wear rate.
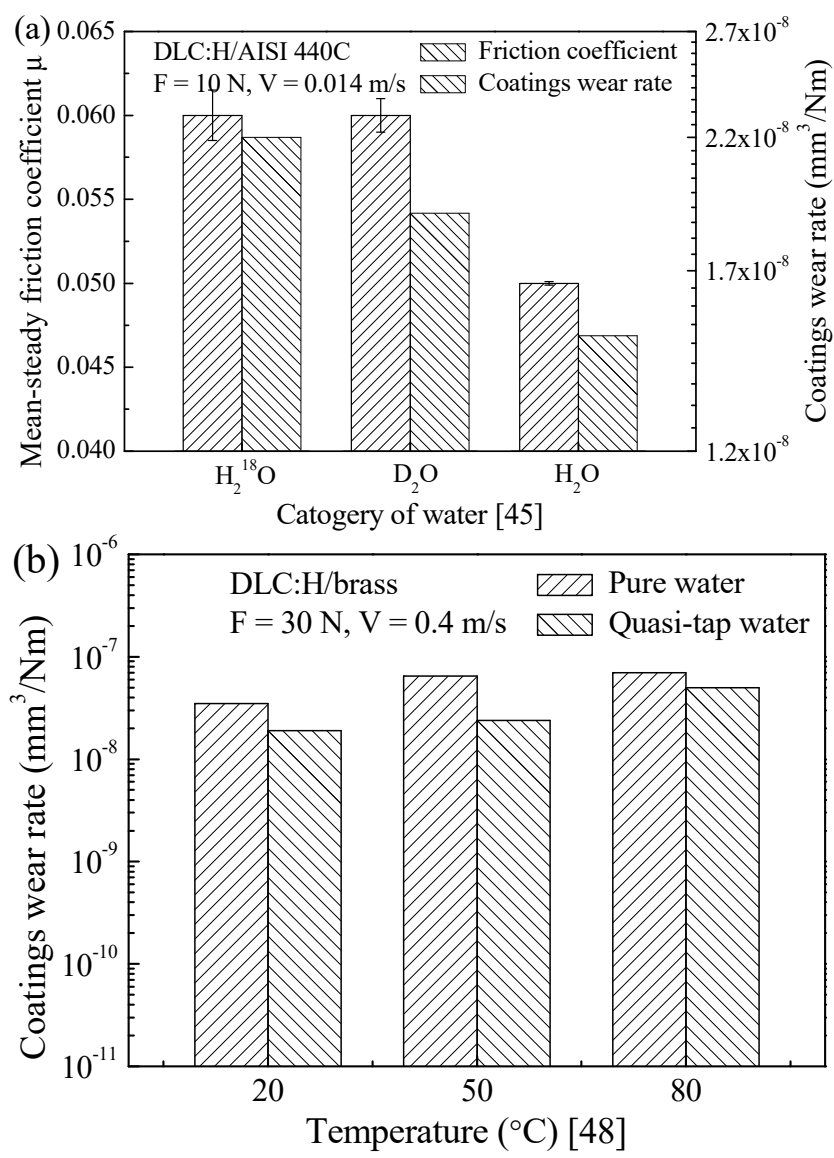

Figure 3. (a) Mean-steady friction coefficient and coating wear rate of the DLC:H/AISI 440C tribopair in different water [45]; (b) wear rate of DLC:H coatings mating with brass in pure and quasi-tap water [48].

According to the thickness of liquid film, lubrication regime could be divided into three categories: boundary lubrication (BL), mixed lubrication (ML) and hydrodynamic lubrication (HL). Obviously, the friction coefficient and wear rate of tribopairs strongly depend on the different lubrication mechanisms. According to the elastohydrodynamic lubrication theory, the thickness of water film is around a few nanometers due to its low viscosity, while the surface roughness of tribopairs commonly varies from 0.5 to $50 \mathrm{~nm}$. Thus, the lubrication regime of DLC coatings under water lubrication is often in boundary lubrication (BL) and mixed lubrication (ML). For instance, the lubrication mechanism of DLC coatings in $[16,22,23,26,38]$ was boundary lubrication with a friction coefficient ranging from 0.08 to 0.11 . In contrast, when a tribochemical layer formed during the friction process, the smoothed friction interface resulted in a fluid lubrication at some spots of the contact interface. Under such a circumstance, the lubrication mechanism of DLC coatings is mixed lubrication (ML), which has been reported in $[19,24,29,39,41]$ with a lower friction coefficient $(0.006$ to 0.10$)$ than that of DLC coatings under boundary lubrication (BL) (see Table 3).

It is obvious that the selection of the water category, working temperature and friction parameter is also a crucial factor to optimize the tribological properties of DLC coatings in water. In other words, DLC:H coatings are expected to present a superior tribological performance mating with 
steel or brass counterparts in hard water at a low temperature; because the heavy ions in hard water can form a tribolayer consisting of $\mathrm{Ca}$ and $\mathrm{O}$ that provides a lubricating effect. Meanwhile, a low water temperature is good for maintaining the viscosity of fluid and beneficial for building a whole lubricating film for DLC coatings in water. If brass is chosen as the counterpart mating with DLC coatings in some applications, tap-water is a better choice to inhibit the accumulation of alumina on brass and contributes to superior tribological properties. The last, but not the least, if the counterpart easily reacts with water and forms a tribochemical layer that could smooth the friction interface, DLC coatings are expected to be rubbed under mixed lubrication (ML) and will present a better tribological performance.

Table 3. Tribological properties of DLC coatings under different lubrication regimes in thewater environment.

\begin{tabular}{lcccccc}
\hline Refs. & Tribopairs & Load (N) & $\begin{array}{c}\text { Velocity } \\
(\mathbf{m} / \mathbf{s})\end{array}$ & $\begin{array}{c}\text { Lubrication } \\
\text { Regime }\end{array}$ & $\begin{array}{c}\text { Friction } \\
\text { Coefficient } \boldsymbol{\mu}\end{array}$ & $\begin{array}{c}\text { Specific Wear } \\
\text { Rate }\left(\mathbf{m m}^{3} / \mathbf{N m}\right)\end{array}$ \\
\hline$[16]$ & $\begin{array}{c}\text { Graphit-iC/tungsten carbide } \\
\text { WC-Co }\end{array}$ & 10 & 0.05 & $\mathrm{BL}$ & 0.10 & $2.3 \times 10^{-8}$ \\
\hline$[22]$ & DLC/stainless steel 316L & 2 & 0.01 & $\mathrm{BL}$ & 0.11 & $6.7 \times 10^{-8}$ \\
\hline$[23]$ & DLC/17-4PH & 2 & 0.5 & $\mathrm{BL}$ & 0.10 & $4.5 \times 10^{-7}$ \\
\hline$[26]$ & DLC/stainless steel AISI 440C & 4.8 & 0.016 & $\mathrm{BL}$ & 0.08 & $3.0 \times 10^{-8}$ \\
\hline$[38]$ & DLC/stainless steel AISI 440C & 1.9 & 0.016 & $\mathrm{BL}$ & 0.08 & - \\
\hline$[19]$ & a-C/a-C & 5 & 0.05 & $\mathrm{ML}$ & 0.03 & $0.5 \times 10^{-8}$ \\
\hline$[24]$ & GLC/WC & 2 & 0.05 & $\mathrm{ML}$ & 0.07 & $1.4 \times 10^{-7}$ \\
\hline$[29]$ & a-C:H:Si/Si3N 4 & 2 & 0.08 & $\mathrm{ML}$ & 0.006 & $1.7 \times 10^{-8}$ \\
\hline$[39]$ & $\mathrm{DLC} /$ stainless steel SUS630 & 4.7 & 0.1 & $\mathrm{ML}$ & 0.10 & - \\
\hline$[41]$ & $\mathrm{Cr} / \mathrm{CrN} / \mathrm{GLC} / \mathrm{FKM} 26$ & 100 & 0.6 & $\mathrm{ML}$ & 0.03 & - \\
\hline
\end{tabular}

\section{Tribological Properties of a- $\mathrm{CN}_{x}$ Coatings under Water Lubrication}

According to the first principle theory, $\beta-C_{3} \mathrm{~N}_{4}$ is expected to be of a higher hardness than diamond due to a similar molecular structure as $\beta-\mathrm{Si}_{3} \mathrm{~N}_{4}$ [51]. Thus, many academics devoted themselves to fabricating $\beta-C_{3} N_{4}$. It turned out that it was hard to synthesize pure $\beta-C_{3} N_{4}$, and almost all of the carbon nitride coatings deposited up to now showed an amorphous structure. Even so, compared with DLC coatings, a- $\mathrm{CN}_{x}$ coatings still presented a higher hardness, as well as a better tribological performance in water.

\subsection{Influence of Microstructure}

It has been reported that under the same load and sliding velocity, the friction coefficient of a-CN $\mathrm{CN}_{x} / \mathrm{SiC}$ tribopairs (0.02 to 0.05$)$ was lower than that of a-C/SiC tribopairs (0.03 to 0.07) in water [52,53]. Zhou et al. [53] confirmed the hydrophilic feature of a-CN $\mathrm{N}_{x}$ coatings and pointed out that the $\mathrm{N}$ atom in a- $\mathrm{CN}_{x}$ coatings was prone to bond with the $\mathrm{H}$ atom in water during the friction process. In that way, the $\mathrm{N}$ atom easily left from the top surface of a- $\mathrm{CN}_{x}$ coatings, and an $\mathrm{sp}^{2} \mathrm{C}=\mathrm{N}$ rich layer with lower shear strength was built. This low shear strength structure contributed to a low friction coefficient.

On the basis of keeping the superior tribological properties of a- $\mathrm{CN}_{x}$ coatings in water, $\mathrm{B}$ was introduced to improve their thermal stability and oxidation resistance. Compared with the a-CN $\mathrm{N}_{x} / \mathrm{SiC}$ tribopair $\left(0.015\right.$ and $\left.4.0 \times 10^{-8} \mathrm{~mm}^{3} / \mathrm{Nm}\right)$, the $\mathrm{BCN} / \mathrm{SiC}$ tribopair presented a much higher friction coefficient and coating wear rate $\left(0.09\right.$ and $\left.1.9 \times 10^{-7} \mathrm{~mm}^{3} / \mathrm{Nm}\right)$, as shown in Figure $4 \mathrm{a}$, but the value of the friction coefficient and wear rate was still acceptable for some applications [54]. When BCN coatings slid against the WC ball, the same friction coefficient of 0.09 and a higher coating wear rate of $1.6 \times 10^{-6} \mathrm{~mm}^{3} / \mathrm{Nm}$ were reported in [55]. In order to optimize the material of counterparts, 
Zhou et al. [56] compared the friction behavior of $\mathrm{BCN}$ coatings sliding against $\mathrm{Al}_{2} \mathrm{O}_{3}, \mathrm{SiC}_{,} \mathrm{Si}_{3} \mathrm{~N}_{4}$ and stainless steel SUS440C in water and pointed out that $\mathrm{BCN}$ coatings exhibited a relatively low friction coefficient when mating with Si-based ceramic balls (see Figure $4 b$ ).
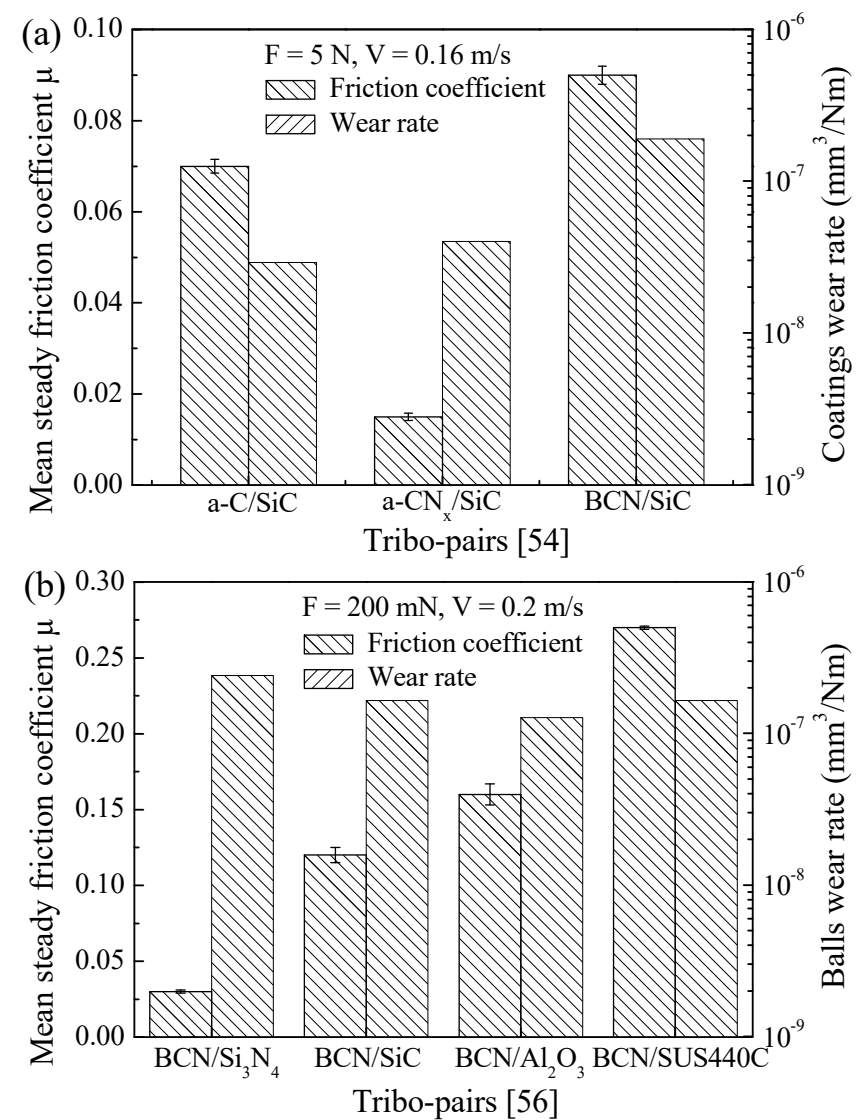

Figure 4. (a) Tribological properties of a-C/SiC, a-CN $\mathrm{CN}_{x} / \mathrm{SiC}$ and $\mathrm{BCN} / \mathrm{SiC}$ tribopairs [54]; (b) tribological properties of BCN coatings sliding against different counterparts [56].

\subsection{Influence of Test Conditions}

In principle, the counterpart, which easily reacts with water to form a lubricating and protective film, will decrease the friction coefficient of tribopairs and enhance the wear resistance of coatings intensively [57]. It is for this reason, under the same load and sliding velocity ( $5 \mathrm{~N}$ and $160 \mathrm{~mm} / \mathrm{s})$, that the friction coefficient of the a-CN $\mathrm{CN}_{x} /$ Si-based tribopair (0.013 0.017) was much lower than that of the a- $\mathrm{CN}_{x} / \mathrm{Fe}$-based tribopair (0.072 0.075), while the a- $\mathrm{CN}_{x} / \mathrm{Al}_{2} \mathrm{O}_{3}$ tribopair showed the highest friction coefficient (0.10) due to the inertness of $\mathrm{Al}_{2} \mathrm{O}_{3}$ in water [58]. On the other hand, friction parameters, such as load and sliding velocity, also impose a non-ignorable impact on coatings' tribology in water. For instance, the friction coefficient of the a- $\mathrm{CN}_{x} / \mathrm{Si}_{3} \mathrm{~N}_{4}$ tribopair raised slightly from 0.019 to 0.020 as the normal load increased from 1.5 to $2.5 \mathrm{~N}$, but subsequently, its friction coefficient decreased sharply from 0.020 to 0.007 as the normal load further increased to $5.0 \mathrm{~N}$ [59].

In order to know the reason for the drop of the friction coefficient for the a- $\mathrm{CN}_{x} / \mathrm{Si}_{3} \mathrm{~N}_{4}$ tribopair at different loads and velocities, Zhou et al. $[60,61]$ set up the wear mechanism maps for a-CN $\mathrm{CN}_{x} / \mathrm{SiC}$ and a- $\mathrm{CN}_{x} / \mathrm{Si}_{3} \mathrm{~N}_{4}$ tribopairs in water and pointed out that their wear mechanisms were strongly dependent on the friction parameters (see Table 4). In their studies, the hydration of Si-based ceramic counterparts ( $\mathrm{SiC}$ and $\mathrm{Si}_{3} \mathrm{~N}_{4}$ ), as Equations (4) and (5), occurred easily. Subsequently, the formed silica gel between the friction interface provided a lubricating and protective effect for tribopairs. 


$$
\begin{gathered}
\mathrm{Si}_{3} \mathrm{~N}_{4}+12 \mathrm{H}_{2} \mathrm{O}=3 \mathrm{Si}(\mathrm{OH})_{4}+4 \mathrm{NH}_{3} \\
\Delta G_{\mathrm{f}}^{298}=-1268.72 \mathrm{~kJ} / \mathrm{mol} \\
\mathrm{SiC}+4 \mathrm{H}_{2} \mathrm{O}=\mathrm{Si}(\mathrm{OH})_{4}+\mathrm{CH}_{4} \\
\Delta G_{\mathrm{f}}^{298}=-598.91 \mathrm{~kJ} / \mathrm{mol}
\end{gathered}
$$

However, high contact pressure was prone to break this silica gel film, and therefore, it was extremely hard to maintain a continuous silica gel film under high load and low sliding velocity. Thus, the main wear mechanism under high load and low velocity was abrasive wear (I in Table 4). In contrast, under low load and high sliding velocity, the lubricating film of silica gel was easily maintained all of the time, and the corresponding wear mechanism became tribochemical wear (IV in Table 4).

Table 4. Wear mechanisms of the a- $-\mathrm{CN}_{x} / \mathrm{SiC}$ and a-CN $\mathrm{CN}_{x} / \mathrm{Si}_{3} \mathrm{~N}_{4}$ tribopairs in distilled water (MW: mechanical wear; TW: tribochemical wear).

\begin{tabular}{ccccccc}
\hline Refs. & Tribopairs & Load $(\mathbf{N})$ & $\begin{array}{c}\text { Velocity } \\
(\mathbf{m} / \mathbf{s})\end{array}$ & $\begin{array}{c}\text { Friction } \\
\text { Coefficient } \boldsymbol{\mu}\end{array}$ & $\begin{array}{c}\text { Coating Wear } \\
\text { Rate }\left(\mathbf{m m}^{\mathbf{3}} / \mathbf{N m}\right)\end{array}$ & Wear Mechanism \\
\hline & & 15 & 0.05 & 0.066 & $8.0 \times 10^{-8}$ & I:MW \\
[60] & a-CN ${ }_{x} / \mathrm{SiC}$ & 9 & 0.1 & 0.041 & $6.5 \times 10^{-8}$ & II: MW+Partial TW \\
& & 6 & 0.3 & 0.033 & $2.7 \times 10^{-8}$ & III: TW+Partial MW \\
& 9 & 0.5 & 0.009 & $2.0 \times 10^{-8}$ & IV: TW \\
\hline & & 12 & 0.05 & 0.094 & $1.9 \times 10^{-7}$ & I:MW \\
[61] & a-CN $\mathrm{CN}_{x} / \mathrm{Si}_{3} \mathrm{~N}_{4}$ & 6 & 0.1 & 0.029 & $9.0 \times 10^{-8}$ & II: MW+Partial TW \\
& & 6 & 0.3 & 0.008 & $6.7 \times 10^{-8}$ & III: TW+Partial MW \\
& & 6 & 0.5 & 0.001 & $2.4 \times 10^{-8}$ & IV: TW \\
\hline
\end{tabular}

As mentioned above, the lubrication mechanism of DLC coatings in water is commonly the boundary and mixed lubrications because the surface asperity is bigger than the thickness of thin water film. Nevertheless, if the material of the counterpart easily reacted with water to form a continuous tribochemical layer, the surface asperity of the friction interface can be reduced to a lower value than the thickness of water film, and then, a hydrodynamic lubrication could be built. As seen in Table 5, the lubrication mechanism of a-CN $\mathrm{CN}_{x}$ coatings mating with $\mathrm{SiC}$ or $\mathrm{Si}_{3} \mathrm{~N}_{4}$ balls was hydrodynamic lubrication due to the hydrated reaction of $\mathrm{SiC}_{\mathrm{Cr}} \mathrm{Si}_{3} \mathrm{~N}_{4}$ (as Equations (4) and (5)), thus resulting in a low friction coefficient, and the coating wear rate varied in the range of 0.001 to 0.032 and $1.1 \times 10^{-8}$ to $1.9 \times 10^{-7} \mathrm{~mm}^{3} / \mathrm{Nm}$, respectively. Moreover, the selection of low load and high velocity is beneficial to form hydrodynamic lubrication for a- $\mathrm{CN}_{x} / \mathrm{SiC}$ and a- $\mathrm{CN}_{x} / \mathrm{Si}_{3} \mathrm{~N}_{4}$ tribopairs $[60,61]$.

The same as DLC coatings, the tribological properties of a-CN $\mathrm{CN}_{x}$ coatings in water are strongly subjected to their microstructure and test conditions. As regarding a- $\mathrm{CN}_{x}$ coatings themselves, those containing a greater fraction of $\mathrm{sp}^{2} \mathrm{C}=\mathrm{N}$ bonds can offer a positive lubricating effect because of the low shear strength. For the selection of the counterpart, Si-based materials, such as $\mathrm{SiC}$ and $\mathrm{Si}_{3} \mathrm{~N}_{4}$, due to the lubricating film formation of silica gel, are much more suitable for mating with a- $\mathrm{CN}_{x}$ coatings under water lubrication compared to steel and alumina counterparts. More importantly, it is better to use a- $\mathrm{CN}_{x}$ coatings under an application condition at a low load and high velocity due to the advantage of hydrodynamic lubrication. 
Table 5. Tribological properties of a- $\mathrm{CN}_{x}$ coatings under different lubrication regimes in the water environment.

\begin{tabular}{|c|c|c|c|c|c|c|}
\hline Refs. & Tribopairs & Load (N) & Velocity (m/s) & $\begin{array}{l}\text { Lubrication } \\
\text { Regime }\end{array}$ & $\begin{array}{c}\text { Friction } \\
\text { Coefficient } \mu\end{array}$ & $\begin{array}{c}\text { Specific Wear } \\
\text { Rate }\left(\mathrm{mm}^{3} / \mathrm{Nm}\right)\end{array}$ \\
\hline$[57]$ & $\mathrm{a}-\mathrm{CN}_{x} / \mathrm{SiC}$ & 3 & 0.15 & $\mathrm{HL}$ & 0.032 & $8.0 \times 10^{-8}$ \\
\hline$[58]$ & $\mathrm{a}-\mathrm{CN}_{x} / \mathrm{Si}_{3} \mathrm{~N}_{4}$ & 5 & 0.16 & $\mathrm{HL}$ & 0.013 & $1.4 \times 10^{-8}$ \\
\hline [59] & $\mathrm{a}-\mathrm{CN}_{x} / \mathrm{Si}_{3} \mathrm{~N}_{4}$ & 5 & 0.16 & HL & 0.007 & $3.9 \times 10^{-8}$ \\
\hline [53] & $\mathrm{a}-\mathrm{CN}_{x} / \mathrm{SiC}$ & $\begin{array}{c}10 \\
5\end{array}$ & $\begin{array}{l}0.16 \\
0.16\end{array}$ & $\begin{array}{l}\text { BL } \\
\text { HL }\end{array}$ & $\begin{array}{l}0.050 \\
0.020\end{array}$ & $\begin{array}{l}3.0 \times 10^{-8} \\
1.1 \times 10^{-8}\end{array}$ \\
\hline$[60]$ & $\mathrm{a}-\mathrm{CN}_{x} / \mathrm{SiC}$ & $\begin{array}{l}3 \\
6 \\
9\end{array}$ & $\begin{array}{c}0.05 \\
0.3 \\
0.5\end{array}$ & $\begin{array}{l}\text { BL } \\
\text { ML } \\
\text { HL }\end{array}$ & $\begin{array}{l}0.085 \\
0.040 \\
0.010\end{array}$ & $\begin{array}{l}1.0 \times 10^{-7} \\
3.0 \times 10^{-8} \\
2.0 \times 10^{-8}\end{array}$ \\
\hline [61] & $\mathrm{a}-\mathrm{CN}_{x} / \mathrm{Si}_{3} \mathrm{~N}_{4}$ & $\begin{array}{c}12 \\
9 \\
6\end{array}$ & $\begin{array}{c}0.05 \\
0.05 \\
0.5\end{array}$ & $\begin{array}{l}\text { BL } \\
\text { ML } \\
\text { HL }\end{array}$ & $\begin{array}{l}0.093 \\
0.027 \\
0.001\end{array}$ & $\begin{array}{l}1.9 \times 10^{-7} \\
1.5 \times 10^{-7} \\
2.5 \times 10^{-8}\end{array}$ \\
\hline
\end{tabular}

\section{Tribological Properties of TiN-Based and CrN-Based Coatings under Water Lubrication}

As the first generation of protective coatings and their modifications, TiN-based and CrN-based coatings have attracted researchers' concerns based on their good tribological properties, as well as strong corrosion resistance in the water environment.

\subsection{Influence of Microstructure}

In order to achieve a lower friction coefficient and stronger wear resistance than those of pure TiN and $\mathrm{CrN}$ coatings, element incorporations, such as $\mathrm{C}, \mathrm{Si}$ and $\mathrm{B}$, which are expected to have a beneficial effect under water lubrication, were proposed by researchers.

As shown in Table 6, TiCN coatings presented a better tribological performance than TiN coatings in air [62-65]. More importantly, the friction coefficient and wear rate of the TiCN/SiC tribopair in water were lower than those in air because of different chemical reactions in different environments [66]. In the air condition, an amount of titanium oxides was formed at the friction interface and acted as abrasive particles to increase the friction coefficient and wear of the tribopair. In contrast, a hydrated lubrication film consisting of $\mathrm{TiO}_{2}$ and $\mathrm{SiO}_{2}$ was formed at the friction interface in water and then resulted in a lower friction coefficient. Based on this result, Wang et al. [67] investigated the correlation between the composition and tribological properties of TiCN coatings in water and pointed out that the $\mathrm{TiCN}(2.46$ at \% C)/SiC tribopair presented the lowest friction coefficient $(0.24)$ and coating wear rate $\left(3.3 \times 10^{-6} \mathrm{~mm}^{3} / \mathrm{Nm}\right)$.

Similarly, Table 7 shows the comparison of the tribological properties between $\mathrm{CrN}$ and $\mathrm{CrCN}$ coatings under dry and water conditions. Obviously, in air, $\mathrm{CrCN}$ coatings exhibited a lower friction coefficient and wear rate than $\mathrm{CrN}$ after $\mathrm{C}$ incorporation [68,69], and their tribological properties were enhanced as the carbon content increased [70]. Nevertheless, for the tribological properties of $\mathrm{CrCN}$ coatings in water, Wang et al. [71] demonstrated that the tribological performance of $\mathrm{CrCN}$ coatings was deteriorated with increasing $\mathrm{C}$ content. However, they also pointed out that the $\mathrm{CrCN}\left(15.35\right.$ at \% C) $/ \mathrm{Si}_{3} \mathrm{~N}_{4}$ tribopair presented the lowest friction coefficient of 0.20 that was always lower than that of $\mathrm{CrCN}$ coatings in the air condition (0.38-0.82). This proves the effect of water from another point of view. 
Table 6. Comparison of the tribological properties of TiN and TiCN coatings under dry and water conditions.

\begin{tabular}{|c|c|c|c|c|c|}
\hline Refs. & Tribopairs & Load (N) & Velocity $(\mathrm{m} / \mathrm{s})$ & $\begin{array}{c}\text { Friction } \\
\text { Coefficient } \mu\end{array}$ & $\begin{array}{c}\text { Coating Wear Rate } \\
\left(\mathrm{mm}^{3} / \mathrm{Nm}\right)\end{array}$ \\
\hline$[62]$ & $\begin{array}{l}\text { TiN/100Cr6 } \\
\text { TiCN/100Cr6 }\end{array}$ & 5 & 0.04 & $\begin{array}{l}\text { Air: } 0.78 \\
\text { Air: } 0.50\end{array}$ & $\begin{array}{l}\text { Air: } 6.0 \times 10^{-7} \\
\text { Air: } 3.5 \times 10^{-6}\end{array}$ \\
\hline [63] & $\begin{array}{c}\mathrm{TiN} / \mathrm{Al}_{2} \mathrm{O}_{3} \\
\text { nc-TiCN/a-SiCN/ } \mathrm{Al}_{2} \mathrm{O}_{3}\end{array}$ & 2.5 & 0.03 & $\begin{array}{l}\text { Air: } 0.49 \\
\text { Air: } 0.18 \\
\end{array}$ & $\begin{array}{l}\text { Air: } 3 \mu \mathrm{m} \text { in depth } \\
\text { Air: } 0.4 \mu \mathrm{m} \text { in depth }\end{array}$ \\
\hline$[64]$ & $\begin{array}{c}\mathrm{TiN} / \mathrm{Al}_{2} \mathrm{O}_{3} \\
\mathrm{TiCN} / \mathrm{Al}_{2} \mathrm{O}_{3} \\
(9.3 \text { at } \% \mathrm{C})\end{array}$ & 1 & - & $\begin{array}{l}\text { Air: } 0.87 \\
\text { Air: } 0.21\end{array}$ & $\begin{array}{l}\text { Air: } 2.5 \times 10^{-6} \\
\text { Air: } 5.3 \times 10^{-7}\end{array}$ \\
\hline [65] & $\begin{array}{c}\mathrm{TiN} / \mathrm{WC} \\
\mathrm{TiC}_{0.7} \mathrm{~N}_{0.3} / \mathrm{WC}\end{array}$ & 6 & 0.2 & $\begin{array}{l}\text { Air: } 0.64 \\
\text { Air: } 0.24\end{array}$ & $\begin{array}{l}\text { Air: } 2.6 \times 10^{-6} \\
\text { Air: } 6.0 \times 10^{-7}\end{array}$ \\
\hline [66] & $\begin{array}{l}\mathrm{TiCN} / \mathrm{SiC} \\
\mathrm{TiCN} / \mathrm{SiC}\end{array}$ & 3 & 0.3 & $\begin{array}{c}\text { Air: } 0.28 \\
\text { Water: } 0.18\end{array}$ & $\begin{array}{c}\text { Air: } 2.8 \times 10^{-6} \\
\text { Water: } 2.7 \times 10^{-6}\end{array}$ \\
\hline [67] & $\operatorname{TiCN}(2.46$ at $\% \mathrm{C}) / \mathrm{SiC}$ & 2 & 0.1 & Water: 0.24 & Water: $3.3 \times 10^{-6}$ \\
\hline
\end{tabular}

Table 7. Comparison of the tribological properties of $\mathrm{CrN}$ and $\mathrm{CrCN}$ coatings under dry and water conditions.

\begin{tabular}{|c|c|c|c|c|c|}
\hline Refs. & Tribopairs & Load (N) & Velocity (m/s) & $\begin{array}{c}\text { Friction } \\
\text { Coefficient } \mu\end{array}$ & $\begin{array}{l}\text { Coating Wear Rate } \\
\left(\mathrm{mm}^{3} / \mathrm{Nm}\right)\end{array}$ \\
\hline [68] & $\begin{array}{c}\text { CrN/steel } \\
\mathrm{CrCN}(39.1 \text { at \% C)/steel }\end{array}$ & 1 & 0.157 & $\begin{array}{l}\text { Air: } 0.60 \\
\text { Air: } 0.50\end{array}$ & - \\
\hline [69] & $\begin{array}{c}\text { CrN/high speed steel (HSS) } \\
\mathrm{CrCN}(7 \text { at \% C)/high speed steel (HSS) }\end{array}$ & 30 & 1.2 & $\begin{array}{l}\text { Air: } 0.56 \\
\text { Air: } 0.45\end{array}$ & $\begin{array}{l}\text { Air: } 7.6 \times 10^{-7} \\
\text { Air: } 2.0 \times 10^{-7}\end{array}$ \\
\hline$[70]$ & $\begin{array}{c}\text { CrN/GCr15 } \\
\mathrm{CrCN}(4.72 \text { at } \% \text { C)/GCr15 } \\
\mathrm{CrCN}(27.13 \text { at } \% \text { C)/GCr15 } \\
\mathrm{CrCN}(46.43 \text { at } \% \text { C) /GCr15 }\end{array}$ & 2 & 0.22 & $\begin{array}{l}\text { Air: } 0.82 \\
\text { Air: } 0.69 \\
\text { Air: } 0.48 \\
\text { Air: } 0.38\end{array}$ & $\begin{array}{l}\text { Air: } 8.3 \times 10^{-6} \\
\text { Air: } 6.9 \times 10^{-6} \\
\text { Air: } 5.2 \times 10^{-6} \\
\text { Air: } 3.8 \times 10^{-6}\end{array}$ \\
\hline$[71]$ & $\begin{array}{l}\mathrm{CrCN}(15.35 \text { at } \% \mathrm{C}) / \mathrm{Si}_{3} \mathrm{~N}_{4} \\
\mathrm{CrCN}(52.60 \text { at } \% \mathrm{C}) / \mathrm{Si}_{3} \mathrm{~N}_{4} \\
\mathrm{CrCN}(74.97 \text { at } \% \mathrm{C}) / \mathrm{Si}_{3} \mathrm{~N}_{4} \\
\mathrm{CrCN}(79.04 \text { at } \% \mathrm{C}) / \mathrm{Si}_{3} \mathrm{~N}_{4}\end{array}$ & 2 & 0.1 & $\begin{array}{l}\text { Water: } 0.20 \\
\text { Water: } 0.42 \\
\text { Water: } 0.44 \\
\text { Water: } 0.50\end{array}$ & $\begin{array}{l}\text { Water: } 2.3 \times 10^{-6} \\
\text { Water: } 2.0 \times 10^{-5} \\
\text { Water: } 5.2 \times 10^{-5} \\
\text { Water: } 3.9 \times 10^{-5}\end{array}$ \\
\hline
\end{tabular}

On the other hand, Masuko et al. [72] investigated the tribological properties of $\mathrm{CrSiN}$ coatings in water. It was found that the friction coefficient of the CrSiN/SUS360 tribopair was higher than that of the CrN/SUS360 tribopair as the sliding velocity was below $0.25 \mathrm{~m} / \mathrm{s}$, but an opposite result was obtained, as the sliding velocity was beyond $0.25 \mathrm{~m} / \mathrm{s}$. It is proven again that the improvement in the tribological properties of coatings with element incorporation cannot be guaranteed. The selection of suitable friction parameters is of paramount importance, as well. Lee et al. [73,74] found that CrSiN coatings lowered the friction coefficient and wear rate of AISI 4340 hydraulic cylinder under low rotating speed (100 to $800 \mathrm{rpm}$ ) and still kept intact without any obvious cracks, even under high rotating speed $(1600 \mathrm{rpm})$. It is indicated that $\mathrm{CrSiN}$ coatings could realize the running of hydraulic pumps under high rotating speed.

As stated before, the tribological properties of the modified coatings is subjected to incorporation content, and the best performance is always obtained at a critical incorporation content. As seen in Figure 5a, Geng et al. [75] found that, as the ratio of $\mathrm{Si} /(\mathrm{Cr}+\mathrm{Si})$ was higher than 5.2 at \%, $\mathrm{CrSiN} /$ WC-Co tribopairs exhibited a lower friction coefficient and coating wear rate than CrN/WC-Co tribopairs in water due to theformation of amorphous silicon oxide. Similarly, Kim et al. [74] and Yamamoto et al. [76] also indicated that a very thin $(<10 \mathrm{~nm})$ silicon hydroxide offered a beneficial lubricating effect, thus contributing to a low friction and good wear resistance for CrSiN coatings 
in water. Besides the incorporations of $\mathrm{Si}$ and $\mathrm{C}$, the influence of $\mathrm{B}$ incorporation on the tribological properties of $\mathrm{CrBN}$ coatings in water was reported in [9]. As shown in Figure 5b, the results showed that the wear resistance of $\mathrm{CrN}$ coatings was enhanced by B incorporation, and the $\mathrm{CrBN}(22.19$ at \% B $) / \mathrm{SiC}$ tribopair displayed the lowest friction coefficient $(0.15)$ and coating wear rate $\left(1.48 \times 10^{-7} \mathrm{~mm}^{3} / \mathrm{Nm}\right)$.
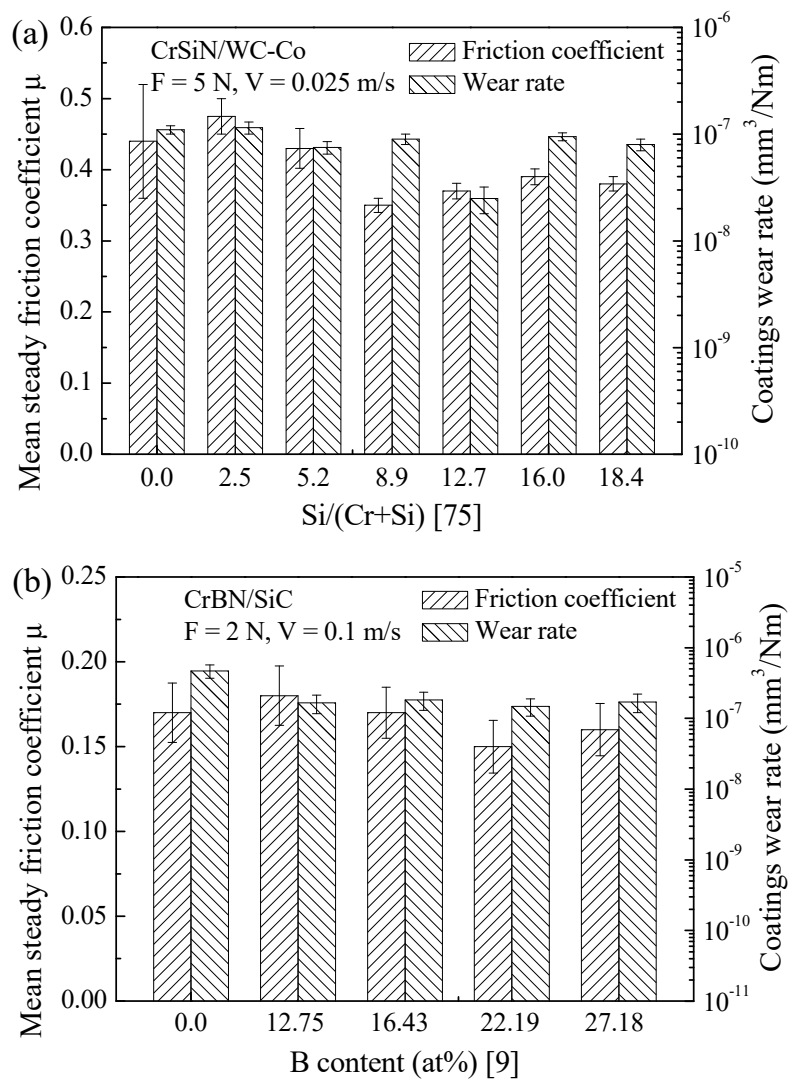

Figure 5. Evolution of the tribological properties of (a) $\mathrm{CrSiN}$ [75] and (b) $\mathrm{CrBN}$ [9] coatings as a function of $\mathrm{Si}$ and B contentunder water lubrication.

Based on the advantages of C, Si and B incorporations stated above, Zhou's group [10-12] further studied the tribological properties of quaternary $\mathrm{CrSiCN}$ and $\mathrm{CrBCN}$ coatings under water lubrication as listed in Table 8. It is demonstrated that the $\mathrm{CrSiCN}(2.05$ at \% $\mathrm{Si}) / \mathrm{SiC}$ tribopair exhibited a lower friction coefficient and wear rate than $\mathrm{CrCN} / \mathrm{SiC}$ tribopair [10], while the $\mathrm{CrSiCN}(2.67$ at \% Si)/SiC tribopair presented the lowest friction coefficient and wear rate [11]. Similarly, after a low incorporation of $\mathrm{B}(\leq 25.1$ at \%), the friction coefficient and wear rate of $\mathrm{CrCN} / \mathrm{SiC}$ tribopair was improved, but a higher B incorporation (27.2 at \%) deteriorated the tribological properties of $\mathrm{CrBCN} / \mathrm{SiC}$ tribopair under water lubrication.

It can be concluded that the incorporation of $\mathrm{C}, \mathrm{Si}$ and $\mathrm{B}$ is able to decrease the friction coefficient and enhance the wear resistance of $\mathrm{TiN}$ and $\mathrm{CrN}$ coatings. However, a critical alloying content is very important to determine whether the tribological properties of TiN and $\mathrm{CrN}$ coatings will be improved or deteriorated. Moreover, this critical doping concentration is closely dependent on the element types. Generally, for $\mathrm{C}$ and $\mathrm{Si}$ alloying, i.e., $\mathrm{TiCN}, \mathrm{CrCN}, \mathrm{CrSiN}$ and $\mathrm{CrSiCN}$ coatings, the optimal alloying range varies from 3.0 at $\%$ to 10 at \%. Within this range, on the one hand, the unchanged coatings structure assures a high hardness. On the other hand, the amorphous carbon phase in $\mathrm{TiCN}$ and $\mathrm{CrCN}$ coatings and silica gel resulted from the reaction of $\mathrm{Si}$ in $\mathrm{CrSiN}$, and $\mathrm{CrSiCN}$ coatings can provide a positive lubricating effect during the friction process. In contrast, for B alloying, i.e., CrBN and CrBCN coatings, a doping concentration around $20-25$ at $\%$ is needed to optimize their tribological performance under water lubrication. 
Table 8. Evolution of the tribological properties of $\mathrm{CrSiCN}$ and $\mathrm{CrBCN}$ coatings in water lubrication as a function of $\mathrm{Si}$ and B content.

\begin{tabular}{|c|c|c|c|c|c|c|}
\hline Refs. & Tribopairs & Water & Load (N) & Velocity $(\mathrm{m} / \mathrm{s})$ & $\begin{array}{c}\text { Friction } \\
\text { Coefficient } \mu\end{array}$ & $\begin{array}{c}\text { Coating Wear } \\
\text { Rate }\left(\mathrm{mm}^{3} / \mathrm{Nm}\right)\end{array}$ \\
\hline \multirow{5}{*}{ [10] } & $\mathrm{CrCN} / \mathrm{SiC}$ & \multirow{5}{*}{ Deionized } & \multirow{5}{*}{2} & \multirow{5}{*}{0.1} & 0.16 & $1.5 \times 10^{-7}$ \\
\hline & $\mathrm{CrSiCN}(2.05$ at $\% \mathrm{Si}) / \mathrm{SiC}$ & & & & 0.11 & $8.4 \times 10^{-8}$ \\
\hline & $\mathrm{CrSiCN}(3.40$ at $\% \mathrm{Si}) / \mathrm{SiC}$ & & & & 0.22 & $2.0 \times 10^{-6}$ \\
\hline & $\mathrm{CrSiCN}(6.20$ at $\% \mathrm{Si}) / \mathrm{SiC}$ & & & & 0.26 & $4.9 \times 10^{-6}$ \\
\hline & $\mathrm{CrSiCN}(7.00$ at $\% \mathrm{Si}) / \mathrm{SiC}$ & & & & 0.27 & $8.1 \times 10^{-6}$ \\
\hline \multirow{3}{*}[11]{} & $\mathrm{CrSiCN}(2.67$ at $\% \mathrm{Si}) / \mathrm{SiC}$ & \multirow{3}{*}{ Deionized } & \multirow{3}{*}{2} & \multirow{3}{*}{0.1} & 0.14 & $2.5 \times 10^{-7}$ \\
\hline & CrSiCN (5.53 at \% Si)/SiC & & & & 0.15 & $1.5 \times 10^{-6}$ \\
\hline & $\mathrm{CrSiCN}(9.86$ at $\% \mathrm{Si}) / \mathrm{SiC}$ & & & & 0.24 & $3.4 \times 10^{-6}$ \\
\hline \multirow{4}{*}[12]{} & $\mathrm{CrCN} / \mathrm{SiC}$ & \multirow{4}{*}{ Deionized } & \multirow{4}{*}{3} & \multirow{4}{*}{0.1} & 0.21 & $5.7 \times 10^{-7}$ \\
\hline & $\mathrm{CrBCN}(24.9$ at $\%$ B) $/ \mathrm{SiC}$ & & & & 0.20 & $4.1 \times 10^{-7}$ \\
\hline & $\mathrm{CrBCN}(25.1$ at \% B) $/ \mathrm{SiC}$ & & & & 0.16 & $2.1 \times 10^{-7}$ \\
\hline & $\mathrm{CrBCN}(27.2$ at $\% \mathrm{~B}) / \mathrm{SiC}$ & & & & 0.22 & $6.3 \times 10^{-7}$ \\
\hline
\end{tabular}

\subsection{Influence of Test Conditions}

As seen in Table 9, Wu et al. [77] compared the tribological properties of the TiN/diamond tribopair between reciprocating and unidirectional sliding in water environment. Although the TiN/diamond tribopair exhibited a lower friction coefficient (0.2-0.3) under reciprocating sliding compared with the unidirectional sliding $(0.5-0.8)$, TiN coatings encountered a higher wear volume because of oxidation under reciprocating sliding. Zhou et al. [78] found that the friction coefficient of the $\mathrm{CrN} / \mathrm{Si}_{3} \mathrm{~N}_{4}$ tribopair in water decreased gradually from 0.42 to 0.34 as the normal load increased from $0.5 \mathrm{~N}$ to $1.5 \mathrm{~N}$. Wang et al. [79-81] compared the tribological properties of $\mathrm{Al}_{2} \mathrm{O}_{3}$ and $\mathrm{CrN}$ coatings sliding against $\mathrm{Si}_{3} \mathrm{~N}_{4}$ in water and found that the $\mathrm{CrN} / \mathrm{Si}_{3} \mathrm{~N}_{4}$ presented a lower friction coefficient and wear rate $\left(0.36-0.51\right.$ and $\left.1.7-3.2 \times 10^{-5} \mathrm{~mm}^{3} / \mathrm{Nm}\right)$ than $\mathrm{Al}_{2} \mathrm{O}_{3} / \mathrm{Si}_{3} \mathrm{~N}_{4}(0.65-0.70$ and $\left.3.8-4.5 \times 10^{-5} \mathrm{~mm}^{3} / \mathrm{Nm}\right)$. However, it is worth nothing that the friction coefficient and coating wear rate of TiN and $\mathrm{CrN}$ coatings are still much higher than those of TiN-based and $\mathrm{CrN}$-based coatings, even though TiN and $\mathrm{CrN}$ coatings remain intact under water lubrication.

Table 9. Tribological properties of TiN and $\mathrm{CrN}$ coatings under water lubrication.

\begin{tabular}{|c|c|c|c|c|c|c|}
\hline Refs. & Tribopairs & Water & Load (N) & Velocity (m/s) & $\begin{array}{c}\text { Friction } \\
\text { Coefficient } \mu\end{array}$ & $\begin{array}{c}\text { Coating Wear } \\
\text { Rate }\left(\mathrm{mm}^{3} / \mathrm{Nm}\right)\end{array}$ \\
\hline \multirow{2}{*}{ [77] } & \multirow{2}{*}{ TiN/diamond } & \multirow{2}{*}{ Demineralized } & \multirow{2}{*}{5} & 0.2 Bidirectional & 0.3 & $5.0 \mu \mathrm{m}$ in depth \\
\hline & & & & 0.2 Unidirectional & 0.6 & $2.3 \mu \mathrm{m}$ in depth \\
\hline \multirow{3}{*}[78]{} & \multirow{3}{*}{$\mathrm{CrN} / \mathrm{Si}_{3} \mathrm{~N}_{4}$} & \multirow{3}{*}{ Distilled } & 0.5 & \multirow{3}{*}{0.04} & 0.42 & $6.0 \times 10^{-6}$ \\
\hline & & & 1.0 & & 0.37 & $4.2 \times 10^{-6}$ \\
\hline & & & 1.5 & & 0.34 & $3.0 \times 10^{-6}$ \\
\hline \multirow{6}{*}{ [79] } & \multirow{6}{*}{$\begin{array}{c}\mathrm{CrN} / \mathrm{Si}_{3} \mathrm{~N}_{4} \\
\mathrm{Al}_{2} \mathrm{O}_{3} / \mathrm{Si}_{3} \mathrm{~N}_{4}\end{array}$} & \multirow{6}{*}{ Pure } & 5.0 & \multirow{6}{*}{0.15} & 0.51 & $1.7 \times 10^{-5}$ \\
\hline & & & 7.5 & & 0.39 & $2.6 \times 10^{-5}$ \\
\hline & & & 10 & & 0.36 & $3.2 \times 10^{-5}$ \\
\hline & & & 5.0 & & 0.70 & $3.8 \times 10^{-5}$ \\
\hline & & & 7.5 & & 0.67 & $4.2 \times 10^{-5}$ \\
\hline & & & 10 & & 0.65 & $4.5 \times 10^{-5}$ \\
\hline
\end{tabular}

The same as DLC coatings, the lubrication mechanism of TiN- and CrN-based coatings is mixed lubrication generally, as listed in Table $10[66,72,75,78,82,83]$. However, because of different mechanical properties and shear strength, the friction coefficient and coating wear rate of TiN-based and CrN-based coatings are higher than those of DLC coatings in Table 3 even under the same lubrication regime. Thus, it is better to use DLC and a-CN $\mathrm{N}_{x}$ coatings under water lubrication if they meet the requirements of application. 
Table 10. Tribological properties of TiN and CrN-based coatings under different lubrication regimes in water environment.

\begin{tabular}{ccccccc}
\hline Refs. & Tribopairs & Load (N) & Velocity $(\mathbf{m} / \mathbf{s})$ & $\begin{array}{c}\text { Lubrication } \\
\text { Regime }\end{array}$ & $\begin{array}{c}\text { Friction } \\
\text { Coefficient } \boldsymbol{\mu}\end{array}$ & $\begin{array}{c}\text { Specific Wear } \\
\text { Rate }\left(\mathbf{m m}^{3} / \mathbf{N m}\right)\end{array}$ \\
\hline$[66]$ & $\mathrm{TiCN} / \mathrm{SiC}$ & 3 & 0.4 & $\mathrm{ML}$ & 0.17 & $2.1 \times 10^{-6}$ \\
\hline$[72]$ & $\mathrm{CrSiN} / \mathrm{SUS630}$ & 20 & 1.0 & $\mathrm{ML}$ & 0.06 & - \\
\hline$[75]$ & $\mathrm{CrSiN} / \mathrm{WC}-\mathrm{Co}$ & 5 & 0.025 & $\mathrm{ML}$ & 0.36 & $2.0 \times 10^{-6}$ \\
\hline$[78]$ & $\mathrm{CrN} / \mathrm{Si}_{3} \mathrm{~N}_{4}$ & 0.5 & 0.01 & $\mathrm{BL}$ & 0.55 & $6.0 \times 10^{-6}$ \\
\hline$[82]$ & $\mathrm{CrCN} / \mathrm{WC}$ & 5 & 0.04 & $\mathrm{ML}$ & 0.35 & $3.0 \times 10^{-6}$ \\
\hline$[83]$ & $\mathrm{CrCN} / \mathrm{WC}$ & 5 & 0.05 & $\mathrm{ML}$ & 0.21 & $6.0 \times 10^{-7}$ \\
\hline
\end{tabular}

Obviously, the friction coefficient of TiN and $\mathrm{CrN}$ coatings under water lubrication is inversely proportional to normal load, but their wear rate is proportional to normal load. Thus, the selection of normal load for TiN and $\mathrm{CrN}$ coatings under water lubrication is dependent on the requested application. However, one thing has to be mentioned here: the friction coefficient of TiN and $\mathrm{CrN}$ coatings under water lubrication is still in a medium range of $0.3-0.6$, while the order of magnitude for the coating wear rate is as high as $10^{-5} \mathrm{~mm}^{3} / \mathrm{Nm}$ [77-81]. Thus, it is better to choose TiCN, CrCN, $\mathrm{CrSiN}, \mathrm{CrBN}, \mathrm{CrSiCN}$ and $\mathrm{CrBCN}$ coatings if a low friction coefficient and wear rate are required.

\section{Summary and Prediction of Nano-Composite Hard Coatings under Water Lubrication}

\subsection{Summary}

DLC, a-CN $\mathrm{CN}_{x}$ and TiN-based and $\mathrm{CrN}$-based coatings, as three major nano-composite materials, present favorable tribological properties under water lubrication. For all types of these coatings, a material that has a self-lubricating effect, such as carbon, or that easily forms lubrication film in water, such as $\mathrm{Cr}, \mathrm{SiC}$ and $\mathrm{Si}_{3} \mathrm{~N}_{4}$, is the best choice for the counterpart. In addition to this, these coatings are better used under a working condition of a low load and a high velocity, because, under such a circumstance, a mixed or even a hydrodynamic lubrication is easy to build. Nevertheless, for each category of these three coatings, there are still some different characteristics stated as below:

In general, the low friction (friction coefficient $<0.1$ ) and wear behavior of DLC and DLC:H coatings is closely attributed to the formation of hydrophilic group $\mathrm{COH}$ or the formation of graphite-containing transfer films. Based on the experimental results so far, hydrogen-free DLC $(\mathrm{a}-\mathrm{C})$ coatings are superior to hydrogenated DLC:H $(\mathrm{a}-\mathrm{C}: \mathrm{H})$ coatings under water lubrication, because delamination may occur on DLC:H (a-C:H) coatings due to the presence of hydrogen. If DLC coatings are chosen to be used, those containing a higher $\mathrm{sp}^{2}$ fraction are more beneficial to present a good tribological performance under water lubrication. In addition, a bi-layer design with a thicker adhesive layer such as Si-DLC:H, Si and $\mathrm{Cr}(\mathrm{N})$ can further improve the tribological properties of DLC coatings under water lubrication. If DLC:H coatings are chosen to be used, it is better to use those containing a low $\mathrm{H}$ concentration and to use them in hard water and at a low temperature.

With regard to a- $\mathrm{CN}_{x}$ coatings, the formation of a $\mathrm{sp}^{2} \mathrm{C}=\mathrm{N}$-rich layer with a low shear strength during the friction process primarily contributes to their low friction coefficient $(<0.1)$. The high hardness of a-CN $\mathrm{CN}_{x}$ coatings essentially guarantees their wear resistance, which is indicated as a low wear rate at the order of magnitude of $10^{-7}$ to $10^{-8} \mathrm{~mm}^{3} / \mathrm{Nm}$.

As compared with DLC and a- $\mathrm{CN}_{x}$ coatings, TiN-based and $\mathrm{CrN}$-based coatings exhibit a slightly higher friction coefficient ( 0.1 to 0.3$)$ and wear rate $\left(10^{-6}\right.$ to $\left.10^{-7} \mathrm{~mm}^{3} / \mathrm{Nm}\right)$ under water lubrication, but they are expected to present a better tribological performance in aggressive solution due to the potential formation of passive film on the top surface. If the requirements of the friction coefficient 
(around 0.1) and wear rate (an order of magnitude of $10^{-7} \mathrm{~mm}^{3} / \mathrm{Nm}$ ) are relatively high, the modified $\mathrm{TiCN}, \mathrm{CrCN}, \mathrm{CrSiN}, \mathrm{CrBN}, \mathrm{CrSiCN}$ and $\mathrm{CrBCN}$ coatings are better to use.

Based on the tribological results stated before, the microstructure of coatings, the materials of the counterparts and the friction parameters are crucial factors to further determine the tribological properties of DLC, a-CN $\mathrm{CN}_{x}$ and TiN-based and CrN-based coatings under water lubrication. To better fit in actual applications, suitable selections of these points are extremely necessary.

\subsection{Prediction}

As time goes on, new categories of coatings are being designed continuously, new technology is being combined with coatings' deposition closely and new application areas of water-lubricated coatings are being expanded. Under such a background, the tribology of nano-composite coatings under water lubrication is being extended to three major aspects: (1) new category of coatings; (2) the combination of texture and nano-composite coatings; (3) new water-based lubricant: sea water.

In addition to the major water-lubricated coatings, i.e., DLC, a- $\mathrm{CN}_{x}$ and TiN/CrN-based, new nano-composite coatings, such as $\mathrm{Al}_{2} \mathrm{O}_{3}-\mathrm{TiO}_{2}$ [84], $\mathrm{Ni}_{3} \mathrm{Si}_{-}-\mathrm{Cr}_{7} \mathrm{C}_{3}$ [85], $\mathrm{B}_{4} \mathrm{C}-\mathrm{hBN}$ [86] and $\mathrm{CrSiC}$ [87], have been investigated in the last four years. The corresponding results indicated that their tribological properties in water were closely related to composition [84-87], friction parameter [85] and the type of counterpart [85,87].

On the other hand, a combination of surface texture and nano-composite coatings is drawing attention from researchers because surface texture is able to reduce the contact area, act as a debris reservoir and provide a dynamic pressure simultaneously under water lubrication. For instance, Ding et al. [88] and Song et al. [89] applied a groove texture on DLC and a-C:H coatings, respectively, to enhance their tribological properties under water lubrication. Furthermore, the improved friction behavior of DLC [90] and $\mathrm{LaF}_{3}-\mathrm{MoS}_{2}$ [91] coatings embedded into dimples on $\mathrm{Al}_{2} \mathrm{O}_{3} / \mathrm{Ni}$ laminated composites has been reported in the last two years.

At last, the ship industry is becoming the priority for the development for economic powers around the world under an important background of ocean exploitation. Subsequently, researchers are starting to focus on the tribological properties of nano-composite coatings in sea water and pointed out the influence of bias voltage [82], chemical composition [83] and the materials of the counterpart [92] on their friction behavior in sea water.

Whether new categories of coating, or the combination of surface texture and coatings, or new application in sea water, more investigations relating to their composition, architecture, counterpart material and friction parameter are extremely needed to optimize their tribological properties in the future.

Acknowledgments: This work was supported by National Natural Science Foundation of China (Grant Nos. 50675102, 50975137, 51375231), the Research Fund for the Doctoral Program of Higher Education (Grant No.20133218110030), the Scientific Research Foundation for the Introduced Talent, Nanjing University of Aeronautics and Astronautics (Grant No. 1005-YAH16043), and the Project Funded by the Priority Academic Program Development of Jiangsu Higher Education Institutions (PAPD).

Conflicts of Interest: The authors declare no conflicts of interest.

\section{References}

1. Dai, W.; Kheireddin, B.; Gao, H.; Liang, H. Roles of nanoparticles in oil lubrication. Tribol. Int. 2016, 102, 88-98. [CrossRef]

2. Kato, K.; Adachi, K. Wear of advanced ceramics. Wear 2002, 253, 1097-1104. [CrossRef]

3. Zhang, S. An approach to the developing ways of tribology in China. Tribology 2001, 21, 321-323. (In Chinese)

4. Wang, Q.; Zhou, F.; Wang, X.; Chen, K.; Wang, M.; Qian, T.; Li, Y. Comparison of tribological properties of $\mathrm{CrN}, \mathrm{TiCN}$ and TiAlN coatings sliding against SiC balls in water. Appl. Surf. Sci. 2011, 257, 7813-7820. [CrossRef] 
5. Zhou, F.; Wang, Q. Low-friction behavior of hard solid coatings in water environment. In Encyclopedia of Tribology, 1st ed.; Wang, Q.J., Chung, Y.-W., Eds.; Springer: New York, NY, USA, 2013; Volume 1, pp. 2020-2023.

6. Moghadam, A.D.; Omrani, E.; Menezes, P.L.; Rohatgi, P.K. Mechanical and tribological properties of self-lubricating metal matrix nanocomposites reinforced by carbon nanotubes (CNTs) and graphene-A review. Compos. Part B: Eng. 2015, 77, 402-420. [CrossRef]

7. Omrani, E.; Moghadam, A.D.; Menezes, P.L.; Rohatgi, P.K. New emerging self-lubricating metal matrix composites for tribological applications. In Ecotribology; Davim, J.P., Ed.; Springer International Publishing: Basel, Switzerland, 2016; pp. 63-103.

8. Moghadam, A.D.; Schultz, B.F.; Ferguson, J.B.; Omrani, E.; Rohatgi, P.K.; Gupta, N. Functional metal matrix composites: Self-lubricating, self-healing, and nanocomposites-an outlook. JOM 2014, 66, 872-881. [CrossRef]

9. Ma, Q.; Zhou, F.; Gao, S.; Wu, Z.; Wang, Q.; Chen, K.; Zhou, Z.; Li, L. Influence of boron content on the microstructure and tribological properties of Cr-B-N coatings in water lubrication. Appl. Surf. Sci. 2016, 377, 394-405. [CrossRef]

10. Wu, Z.; Zhou, F.; Chen, K.; Wang, Q.; Zhou, Z.; Yan, J.; Li, L. Friction and wear properties of CrSiCN coatings with low carboncontent as sliding against $\mathrm{SiC}$ and steel balls in water. Tribol. Int. 2016, 94, 176-186. [CrossRef]

11. Wu, Z.; Zhou, F.; Wang, Q.; Zhou, Z.; Yan, J.; Li, L. Influence of trimethylsilane flow on the microstructure, mechanical and tribological properties of $\mathrm{CrSiCN}$ coatings in water lubrication. Appl. Surf. Sci. 2015, 355, 516-530. [CrossRef]

12. Ma, Q.; Zhou, F.; Wang, Q.; Wu, Z.; Chen, K.; Zhou, Z.; Li, L. Influence of $\mathrm{CrB}_{2}$ target current on themicrostructure, mechanical and tribologicalproperties of Cr-B-C-N coatings in water. RSC Adv. 2016, 6, 47698-47711. [CrossRef]

13. Wang, Q. Microstructure, Mechanical, Tribological and Corrosion Properties of Carbon/Nitride-BasedCoatings in Aqueous Environment. Ph.D. Thesis, Nanjing University of Aeronautics and Astronautics, Nanjing, China, 2013. (In Chinese)

14. Ronkainen, H.; Varjus, S.; Holmberg, K. Tribological performance of different DLC coatings in water-lubricated conditions. Wear 2001, 249, 267-271. [CrossRef]

15. Ronkainen, H.; Varjus, S.; Holmberg, K. Friction and wear properties in dry, water- and oil-lubricated DLC against alumina and DLC against steel contacts. Wear 1998, 222, 120-128. [CrossRef]

16. Stallard, J.; Mercs, D.; Jarratt, M.; Teer, D.; Shipway, P. A study of the tribological behaviour of three carbon-based coatings, tested in air, water and oil environments at high loads. Surf. Coat. Technol. 2004, 177-178, 545-551. [CrossRef]

17. Andersson, J.; Erck, R.A.; Erdemir, A. Frictional behavior of diamond-like carbon films in vacuum and under varying water vapor pressure. Surf. Coat. Technol. 2003, 163-164, 535-540. [CrossRef]

18. Andersson, J.; Erck, R.A.; Erdemir, A. Friction of diamond-like carbon films in different atmospheres. Wear 2003, 254, 1070-1075. [CrossRef]

19. Wang, L.; Wang, Y.; Wang, Y.; Xue, Q. Tribological performances of non-hydrogenated amorphous carbon coupling with different coating counterparts in ambient air and water. Wear 2013, 300, 20-28. [CrossRef]

20. Zhang, J.; Huang, L.; Yu, L.; Zhang, P. Synthesis and tribological behaviors of diamond-like carbon films by electrodeposition from solution of acetonitrile and water. Appl. Surf. Sci. 2008, 254, 3896-3901. [CrossRef]

21. Suzuki, M.; Ohana, T.; Tanaka, A. Tribological properties of DLC films with different hydrogen contents in water environment. Diam. Relat. Mater. 2004, 13, 2216-2220. [CrossRef]

22. Statuti, R.; Radi, P.; Santos, L.; Trava-Airoldi, V. A tribological study of the hybrid lubrication of DLC films with oil and water. Wear 2009, 267, 1208-1213. [CrossRef]

23. Yamamoto, K.; Matsukado, K. Effect of hydrogenated DLC coating hardness on the tribological properties in water lubrication. Tribol. Int. 2006, 39, 1609-1614. [CrossRef]

24. Wang, Y.; Li, J.; Shan, L.; Chen, J.; Xue, Q. Tribological performances of the graphite-like carbon films deposited with different target powers in ambient air and distilled water. Tribol. Int. 2014, 73, 17-24. [CrossRef]

25. Tanaka, A.; Suzuki, M.; Ohana, T. Friction and wear of various DLC films in water and air environments. Tribol. Lett. 2004, 17, 917-924. [CrossRef] 
26. Wu, X.; Suzuki, M.; Ohana, T.; Tanaka, A. Characteristics and tribological properties in water of Si-DLC coatings. Diam. Relat. Mater. 2008, 17,7-12. [CrossRef]

27. Vila, M.; Carrapichano, J.; Gomes, J.; Camargo, S., Jr.; Achete, C.; Silva, R. Ultra-high performance of DLC-coated $\mathrm{Si}_{3} \mathrm{~N}_{4}$ rings for mechanical seals. Wear 2008, 265, 940-944. [CrossRef]

28. Suzuki, M.; Tanaka, A.; Ohana, T.; Zhang, W. Frictional behavior of DLC films in a water environment. Diam. Relat. Mater. 2004, 13, 1464-1468. [CrossRef]

29. Zhao, F.; Li, H.; Ji, L.; Mo, Y.; Quan, W.; Du, W.; Zhou, H.; Chen, J. Superlow friction behavior of Si-doped hydrogenated amorphous carbon film in water environment. Surf. Coat. Technol. 2009, 203, 981-985. [CrossRef]

30. Ohana, T.; Suzuki, M.; Nakamura, T.; Tanaka, A.; Koga, Y. Low-friction behaviour of diamond-like carbon films in a water environment. Diam. Relat. Mater. 2006, 15, 962-966. [CrossRef]

31. Wang, Q.; Zhou, F.; Zhou, Z.; Yang, Y.; Yan, C.; Wang, C.; Zhang, W.; Li, L.; Bello, I.; Lee, S. Influence of Ti content on the structure and tribological properties of Ti-DLC coatings in water lubrication. Diam. Relat. Mater. 2012, 25, 163-175. [CrossRef]

32. Wang, Q.; Zhou, F.; Ding, X.; Zhou, Z.; Wang, C.; Zhang, W.; Li, L.; Lee, S. Structure and water-lubricated tribological properties of $\mathrm{Cr}$ /a-C coatings with different $\mathrm{Cr}$ contents. Tribol. Int. 2013, 67, 104-115. [CrossRef]

33. Wang, Q.; Zhou, F.; Ding, X.; Zhou, Z.; Zhang, W.; Li, L.; Lee, S. Influences of ceramic mating balls on the tribological properties of $\mathrm{Cr}$ /a-C coatings with low chromium content in water lubrication. Wear 2013, 303, 354-360. [CrossRef]

34. Ohana, T.; Suzuki, M.; Nakamura, T.; Tanaka, A.; Koga, Y. Friction behaviour of Si-DLC/DLC multi layer films on steel substrate in water environment. Diam. Relat. Mater. 2005, 14, 1089-1093. [CrossRef]

35. Park, S.; Lee, K.; Ahn, S.; Kim, J. Instability of diamond-like carbon (DLC) films during sliding in aqueous environment. Diam. Relat. Mater. 2008, 17, 247-251. [CrossRef]

36. Wang, L.; Nie, X.; Lukitsch, M.; Jiang, J.; Cheng, Y. Effect of tribological media on tribological properties of multilayer Cr(N)/C(DLC) coatings. Surf. Coat. Technol. 2006, 201, 4341-4347. [CrossRef]

37. Ohana, T.; Suzuki, M.; Nakamura, T.; Tanaka, A.; Koga, Y. Tribological properties of DLC films deposited on steel substrate with various surface roughness. Diam. Relat. Mater. 2004, 13, 2211-2215. [CrossRef]

38. Ohana, T.; Wu, X.; Nakamura, T.; Tanaka, A. Roughness effect of mating ball on friction of diamond-like carbon film and friction mechanism in water and air environment. Diam. Relat. Mater. 2008, 17, 860-863. [CrossRef]

39. Tokoro, M.; Aiyama, Y.; Masuko, M.; Suzuki, A.; Ito, H.; Yamamoto, K. Improvement of tribological characteristics under water lubrication of DLC-coatings by surface polishing. Wear 2009, 267, 2167-2172. [CrossRef]

40. Lei, X.; Shen, B.; Chen, S.; Wang, L.; Sun, F. Tribological behavior between micro- and nano-crystalline diamondfilms under dry sliding and water lubrication. Tribol. Int. 2014, 69, 118-127. [CrossRef]

41. Wang, L.; Guan, X.; Zhang, G. Friction and wear behaviors of carbon-based multilayer coatings sliding against different rubbers in water environment. Tribol. Int. 2013, 64, 69-77. [CrossRef]

42. Zhang, T.; Jiang, F.; Liao, T.; Deng, Q.; Li, S.; Wang, Y.; Leng, Y. Tribological behavior of diamond like carbon film sliding againstCoCrMo or $\mathrm{Al}_{2} \mathrm{O}_{3}$ in air and water environment. Tribol. Int. 2016, 95, 456-461. [CrossRef]

43. Wang, Y.; Wang, L.; Li, J.; Chen, J.; Xue, Q. Tribological properties of graphite-like carbon coatings coupling with different metals in ambient air and water. Tribol. Int. 2013, 60, 147-155. [CrossRef]

44. Ohana, T.; Wu, X.; Nakamura, T.; Tanaka, A. Formation of lubrication film of diamond-like carbon films in water and airenvironments against stainless steel and Cr-plated balls. Diam. Relat. Mater. 2007, 16, 1336-1339. [CrossRef]

45. Wu, X.; Ohana, T.; Tanaka, A.; Kubo, T.; Nanao, H.; Minami, I.; Mori, S. Tribochemical investigation of DLC coating in water using stable isotopic tracers. Appl. Surf. Sci. 2008, 254, 3397-3402. [CrossRef]

46. Wu, X.; Ohana, T.; Tanaka, A.; Kubo, T.; Nanao, H.; Minami, I.; Mori, S. Tribochemical investigation of DLC coating tested against steel in water using a stable isotopic tracer. Diam. Relat. Mater. 2007, 16, 1760-1764. [CrossRef]

47. Wu, X.; Ohana, T.; Tanaka, A.; Kubo, T.; Nanao, H.; Minami, I.; Mori, S. Tribochemical reaction of Si-DLC coating in water studied by stable isotopic tracer. Diam. Relat. Mater. 2008, 17, 147-153. [CrossRef]

48. Uchidate, M.; Liu H, B.; Iwabuchi, A.; Yamamoto, K. Effects of water environment on tribological properties of DLC rubbed against brass. Wear 2009, 267, 1589-1594. [CrossRef] 
49. Uchidate, M.; Liu, H.; Yamamoto, K.; Iwabuchi, A. Effects of hard water on tribological properties of DLC rubbed against stainless steel and brass. Wear 2013, 308, 79-85. [CrossRef]

50. Uchidate, M.; Liu, H.; Iwabuchi, A.; Yamamoto, K. Effects of water environment on tribological properties of DLC rubbed against stainless steel. Wear 2007, 263, 1335-1340. [CrossRef]

51. Liu, A.; Cohen, M. Prediction of new low compressibility solids. Science 1989, 245, 841-842. [CrossRef] [PubMed]

52. Zhou, F.; Adachi, K.; Kato, K. Sliding friction and wear property of a-C and a-CN $\mathrm{N}_{x}$ coatings against $\mathrm{SiC}$ ball in water. Thin Solid Films 2006, 514, 231-239. [CrossRef]

53. Zhou, F.; Kato, K.; Adachi, K. Friction and wear properties of $\mathrm{CN}_{x} / \mathrm{SiC}$ in water lubrication. Tribol. Lett. 2005, 18, 153-163. [CrossRef]

54. Zhou, F.; Adachi, K.; Kato, K. Comparisons of tribological properties of a-C, a-CN $\mathrm{N}_{x}$ and BCN coatings sliding against $\mathrm{SiC}$ balls in water. Surf. Coat. Technol. 2006, 200, 4471-4478. [CrossRef]

55. Carettia, I.; Albella J, M.; Jimenez, I. Friction and wear of amorphous $\mathrm{BC}_{4} \mathrm{~N}$ coatings under different atmospheres. Diam. Relat. Mater. 2007, 16, 1445-1449. [CrossRef]

56. Zhou, F.; Adachi, K.; Kato, K. Friction and wear behavior of BCN coatings sliding against ceramic and steel balls in various environments. Wear 2006, 261, 301-310. [CrossRef]

57. Zhou, F.; Yue, B.; Wang, Q.; Wang, X.; Koshi, A.; Kato, K. Tribological properties of a-CN $\mathrm{CN}_{x}$ coatings sliding against $\mathrm{SiC}$ ballsin ethylene glycol aqueous solution. Lubrication Sci. 2010, 22, 225-236. [CrossRef]

58. Zhou, F.; Adachi, K.; Kato, K. Friction and wear properties of a- $\mathrm{CN}_{x}$ coatings sliding against ceramic and steel ball in water. Diam. Relat. Mater. 2005, 14, 1711-1720. [CrossRef]

59. Zhou, F.; Wang, X.; Kato, K.; Dai, Z. Friction and wear property of a- $\mathrm{CN}_{x}$ coatings sliding against $\mathrm{Si}_{3} \mathrm{~N}_{4}$ balls in water. Wear 2007, 263, 1253-1258. [CrossRef]

60. Zhou, F.; Adachi, K.; Kato, K. Wear-mechanism map of amorphous carbon nitride coatings sliding against silicon carbide balls in water. Surf. Coat. Technol. 2006, 200, 4909-4917. [CrossRef]

61. Zhou, F.; Wang, X.; Adachi, K.; Kato, K. Influence of normal load and sliding speed on the tribological property of amorphous carbon nitride coatings sliding against $\mathrm{Si}_{3} \mathrm{~N}_{4}$ balls in water. Surf. Coat. Technol. 2008, 202, 3519-3528. [CrossRef]

62. Polcar, T.; Kubart, T.; Novak, R.; Kopecky, L.; Siroky, P. Comparison of tribological behaviour of TiN, TiCN and CrN at elevated temperatures. Surf. Coat. Technol. 2005, 193, 192-199. [CrossRef]

63. Guruvenket, S.; Li, D.; Klemberg-Sapieha, J.; Martinu, L.; Szpunar, J. Mechanical and tribological properties of duplex treated TiN, nc-TiN/a-SiN $\mathrm{x}$ and nc-TiCN/a-SiCN coatings deposited on 410 low alloy stainless steel. Surf. Coat. Technol. 2009, 203, 2905-2911. [CrossRef]

64. Cheng, Y.; Browne, T.; Heckerman, B.; Meletis, E. Influence of the C content on the mechanical and tribological properties of the TiCN coatings deposited by LAFAD technique. Surf. Coat. Technol. 2011, 205, 4024-4029. [CrossRef]

65. Zhang, G.; Li, B.; Jiang, B.; Yan, F.; Chen, D. Microstructure and tribological properties of TiN, TiC and Ti(C, $\mathrm{N})$ thin films prepared by closed-field unbalanced magnetron sputtering ion plating. Appl. Surf. Sci. 2009, 255, 8788-8793.

66. Wang, Q.; Zhou, F.; Chen K, M.; Wang, M.; Qian, T. Friction and wear properties of TiCN coatings sliding against $\mathrm{SiC}$ and steel balls in air and water. Thin Solid Films 2011, 519, 4830-4841. [CrossRef]

67. Wang, Q.; Zhou, F.; Zhou, Z.; Yang, Y.; Yan, C.; Wang, C.; Zhang, W.; Li, L.; Bello, I.; Lee, S. Influence of carbon content on the microstructure and tribological properties of $\mathrm{TiN}(\mathrm{C})$ coatings in water lubrication. Surf. Coat. Technol. 2012, 206, 3777-3787. [CrossRef]

68. Choi, E.; Kang, M.; Kwon, D.H.; Shin, D.; Kim, K. Comparative studies on microstructure and mechanical properties of CrN, Cr-C-N and Cr-Mo-N coatings. J. Mater. Process. Technol. 2007, 187-188, 566-570. [CrossRef]

69. Warcholinski, B.; Gilewicz, A.; Kuklinski, Z.; Myslinski, P. Hard CrCN/CrN multilayer coatings for tribological applications. Surf. Coat. Technol. 2010, 204, 2289-2293. [CrossRef]

70. Hu, P.; Jiang, B. Study on tribological property of $\mathrm{CrCN}$ coating based on magnetron sputtering plating technique. Vacuum 2011, 85, 994-998.

71. Wang, Q.; Zhou, F.; Ding, X.; Zhou, Z.; Wang, C.; Zhang, W.; Li, L.; Lee, S. Microstructure and water-lubricated friction and wear properties of $\mathrm{CrN}(\mathrm{C})$ coatings with different carbon contents. Appl. Surf. Sci. 2013, 268, 579-587. [CrossRef] 
72. Masuko, M.; Suzuki, A.; Sagae, Y.; Tokoro, M.; Yamamoto, K. Friction characteristics of inorganic or organic thin coatings on solid surfaces under water lubrication. Tribol. Int. 2006, 39, 1601-1608. [CrossRef]

73. Lee, S.; Hong, Y. Effect of CrSiN thin film coating on the improvement of the low-speed torque efficiency of a hydraulic piston pump. Surf. Coat. Technol. 2007, 202, 1129-1134. [CrossRef]

74. Kim, G.; Kim, B.; Lee, S. High-speed wear behaviors of CrSiN coatings for the industrial applications of water hydraulics. Surf. Coat. Technol. 2005, 200, 1814-1818. [CrossRef]

75. Geng, Z.; Wang, H.; Wang, C.; Wang, L.; Zhang, G. Effect of Si content on the tribological properties of CrSiN films in air andwater environments. Tribol. Int. 2014, 79, 140-150. [CrossRef]

76. Yamamoto, K.; Oomoto, S. The effect of Si content and substrate bias on structural and tribological properties of $(\mathrm{Cr}, \mathrm{Si}) \mathrm{N}$ coatings under water lubrication. In Tribol. Interface Eng Ser; Dowson, D., Priest, M., Dalmaz, G., Lubrecht, A., Eds.; Elsevier: Amsterdam, The Netherlands, 2005; Volume 48, pp. 401-407.

77. Wu, P.; Drees, D.; Stals, L.; Celis, J.P. Comparison of wear and corrosion wear of TiN coatings under uni- and bidirectional sliding. Surf. Coat. Technol. 1999, 113, 251-258. [CrossRef]

78. Zhou, F.; Chen, K.; Wang, M.; Xu, X.; Meng, H.; Yu, M.; Dai, Z. Friction and wear properties of CrN coatings sliding against $\mathrm{Si}_{3} \mathrm{~N}_{4}$ balls in water and air. Wear 2008, 265, 1029-1037. [CrossRef]

79. Wang, Y. Research on Tribological Properties of Alumina Ceramic Coating by Micro-Arc Oxidation (MAO) and Modified Coating on Aluminum Alloy. Master Thesis, Nanjing University of Aeronautics and Astronautics, Nanjing, China, 2007. (In Chinese)

80. Wang, Y.; Wang, M.; Zhou, F.; Ding, H.; Dai, Z. Tribological properties of ceramic coating prepared by micro-arc oxidation for aluminum alloys in various environments. Trans. Nonferr. Metal Soc. 2007, 17, 1266-1272. (In Chinese)

81. Zhou, F.; Wang, Y.; Ding, H.; Wang, M.; Yu, M.; Dai, Z. Friction characteristic of micro-arc oxidative $\mathrm{Al}_{2} \mathrm{O}_{3}$ coatings sliding against $\mathrm{Si}_{3} \mathrm{~N}_{4}$ balls in various environments. Surf. Coat. Technol. 2008, 202, 3808-3814. [CrossRef]

82. Ye, Y.; Wang, Y.; Chen, H.; Li, J.; Zhou, S.; Xue, Q. Influences of bias voltage on the microstructures and tribological performances of Cr-C-N coatings in seawater. Surf. Coat. Technol. 2015, 270, 305-313. [CrossRef]

83. Ye, Y.; Wang, Y.; Wang, C.; Li, J.; Yao, Y. An analysis on tribological performance of CrCN coatings with differentcarbon contents in seawater. Tribol. Int. 2015, 91, 131-139. [CrossRef]

84. Wu, D.; Liu, Y.; Zhao, X.; Li, D.; Ren, X. The tribological behaviors of different mass ratio $\mathrm{Al}_{2} \mathrm{O}_{3}-\mathrm{TiO}_{2}$ coatings in water lubrication sliding against $\mathrm{Si}_{3} \mathrm{~N}_{4}$. Tribol. Trans. 2016, 59, 352-362. [CrossRef]

85. Niu, M.; Bi, Q.; Yang, J.; Liu, W. Tribological performances of $\mathrm{Ni}_{3} \mathrm{Si}_{-} \mathrm{Cr}_{7} \mathrm{C}_{3}$ composite coatings under water and acid environments. Tribol. Int. 2012, 48, 216-225. [CrossRef]

86. Li, X.; Gao, Y.; Yang, Q.; Pan, W.; Li, Y.; Zhong, Z.; Song, L. Evaluation of tribological behavior of $\mathrm{B}_{4} \mathrm{C}-\mathrm{hBN}$ ceramic compositesunder water-lubricated condition. Ceram. Int. 2015, 41, 7387-7393. [CrossRef]

87. Wu, Z.; Zhou, F.; Chen, K.; Wang, Q.; Zhou, Z.; Yan, J.; Li, L. Microstructure, mechanical and tribological properties of $\mathrm{CrSiC}$ coatings sliding against $\mathrm{SiC}$ and $\mathrm{Al}_{2} \mathrm{O}_{3}$ balls in water. Appl. Surf. Sci. 2016, 368, 129-139. [CrossRef]

88. Ding, Q.; Wang, L.; Wang, Y.; Wang, S.; Hu, L.; Xue, Q. Improved Tribological behavior of DLC films under water lubrication by surface texturing. Tribol. Lett. 2011, 41, 439-449. [CrossRef]

89. Song, H.; Ji, L.; Li, H.; Liu, X.; Zhou, H.; Liu, L.; Chen, J. Superlow Friction behavior of surface-textured a-C:H film in water environments. Tribol. Trans. 2016, 58, 867-874. [CrossRef]

90. Fan, H.; Zhang, Y.; Hu, T.; Song, J.; Ding, Q.; Hu, L. Surface composition-lubrication design of $\mathrm{Al}_{2} \mathrm{O}_{3} / \mathrm{Ni}$ laminatedcomposites-Part I: Tribological synergy effect of micro-dimpledtexture and diamond-like carbon films in a water environment. Tribol. Int. 2015, 84, 142-151. [CrossRef]

91. Fan, H.; Hu, T.; Wan, H.; Zhang, Y.; Song, J.; Hu, L. Surface composition-lubrication design of $\mathrm{Al}_{2} \mathrm{O}_{3} / \mathrm{Ni}$ laminatedcomposites-Part II: Tribological behavior of $\mathrm{LaF}_{3}$-doped $\mathrm{MoS}_{2}$ composite coating in a water environment. Tribol. Int. 2016, 96, 258-268. [CrossRef]

92. Wang, C.; Ye, Y.; Guan, X.; Hu, J.; Wang, Y.; Li, J. An analysis of tribological performance on Cr/GLC film couplingwith $\mathrm{Si}_{3} \mathrm{~N}_{4}, \mathrm{SiC}, \mathrm{WC}, \mathrm{Al}_{2} \mathrm{O}_{3}$ and $\mathrm{ZrO}_{2}$ in seawater. Tribol. Int. 2016, 96, 77-86. [CrossRef]

(C) 2017 by the authors; licensee MDPI, Basel, Switzerland. This article is an open access article distributed under the terms and conditions of the Creative Commons Attribution (CC BY) license (http:/ / creativecommons.org/licenses/by/4.0/). 